\title{
Validity of activity monitors in health and chronic disease: a systematic review
}

Hans Van Remoortel ${ }^{1 \dagger}$, Santiago Giavedoni ${ }^{2 \dagger}$, Yogini Raste ${ }^{3}$, Chris Burtin ${ }^{1}$, Zafeiris Louvaris ${ }^{4}$, Elena Gimeno-Santos ${ }^{5}$, Daniel Langer ${ }^{1}$, Alastair Glendenning ${ }^{6}$, Nicholas S Hopkinson ${ }^{3}$, Ioannis Vogiatzis ${ }^{4}$, Barry T Peterson ${ }^{7}$, Frederick Wilson ${ }^{7}$, Bridget Mann ${ }^{6}$, Roberto Rabinovich ${ }^{2}$, Milo A Puhan ${ }^{8,9}$ and Thierry Troosters ${ }^{1,11^{*}}$, on behalf of PROactive consortium

\begin{abstract}
The assessment of physical activity in healthy populations and in those with chronic diseases is challenging. The aim of this systematic review was to identify whether available activity monitors (AM) have been appropriately validated for use in assessing physical activity in these groups. Following a systematic literature search we found 134 papers meeting the inclusion criteria; 40 conducted in a field setting (validation against doubly labelled water), 86 in a laboratory setting (validation against a metabolic cart, metabolic chamber) and 8 in a field and laboratory setting. Correlation coefficients between AM outcomes and energy expenditure (EE) by the criterion method (doubly labelled water and metabolic cart/chamber) and percentage mean differences between EE estimation from the monitor and EE measurement by the criterion method were extracted. Random-effects meta-analyses were performed to pool the results across studies where possible. Types of devices were compared using metaregression analyses. Most validation studies had been performed in healthy adults $(n=118)$, with few carried out in patients with chronic diseases $(n=16)$. For total $E E$, correlation coefficients were statistically significantly lower in uniaxial compared to multisensor devices. For active EE, correlations were slightly but not significantly lower in uniaxial compared to triaxial and multisensor devices. Uniaxial devices tended to underestimate TEE $(-12.07(95 \% \mathrm{Cl}$; -18.28 to -5.85$) \%)$ compared to triaxial $(-6.85(95 \% \mathrm{Cl} ;-18.20$ to 4.49$) \%, p=0.37)$ and were statistically significantly less accurate than multisensor devices $(-3.64(95 \% \mathrm{Cl} ;-8.97$ to 1.70$) \%, \mathrm{p}<0.001)$. TEE was underestimated during slow walking speeds in $69 \%$ of the lab validation studies compared to $37 \%, 30 \%$ and $37 \%$ of the studies during intermediate, fast walking speed and running, respectively. The high level of heterogeneity in the validation studies is only partly explained by the type of activity monitor and the activity monitor outcome. Triaxial and multisensor devices tend to be more valid monitors. Since activity monitors are less accurate at slow walking speeds and information about validated activity monitors in chronic disease populations is lacking, proper validation studies in these populations are needed prior to their inclusion in clinical trials.
\end{abstract}

Keywords: Chronic diseases, Doubly labelled water, Indirect calorimetry, Activity monitoring, Physical activity, Validation study, Systematic review

\footnotetext{
* Correspondence: thierry.troosters@med.kuleuven.be

${ }^{\dagger}$ Equal contributors

${ }^{1}$ Faculty of Kinesiology and Rehabilitation Sciences, Department of

Rehabilitation Sciences, Katholieke Universiteit Leuven, Leuven, Belgium and

Respiratory Division, UZ Gasthuisberg, Leuven, Belgium

${ }^{11}$ Respiratory Rehabilitation and Respiratory Division, UZ Gasthuisberg,

Herestraat 49 bus 706, Onderwijs \& Navorsing I, Labo Pneumologie, B-3000,

Leuven, Belgium

Full list of author information is available at the end of the article
}

\section{Biomed Central}

(c) 2012 Van Remoortel et al.; licensee BioMed Central Ltd. This is an Open Access article distributed under the terms of the Creative Commons Attribution License (http://creativecommons.org/licenses/by/2.0), which permits unrestricted use, distribution, and reproduction in any medium, provided the original work is properly cited. 


\section{Systematic review Introduction}

There is evidence that regular physical activity is associated with a reduced risk of mortality and contributes to the primary and secondary prevention of several chronic diseases [1]. For example, a reduced risk of coronary heart disease, cardiovascular disease, stroke and colon cancer has been reported in more active individuals [2]. In patients with chronic obstructive pulmonary disease (COPD), regular physical activity leads to a lower risk of both COPD related hospital admissions and mortality [3]. Physical activity limitation is a major problem in patients with chronic diseases and needs to be accurately measured if therapies aimed at improving this are to be properly evaluated. A range of devices are available for this purpose but most have been validated in young, healthy subjects and their applicability to older or unwell populations, where movements tend to be slower, is not well established.

Physical activity is defined as any bodily movement, produced by skeletal muscles, requiring energy expenditure
[4]. Daily physical activity can be considered as "the totality of voluntary movement produced by skeletal muscles during everyday functioning" [5]. Estimates of daily physical activity can be obtained by different approaches; questionnaires, energy expenditure measurements and activity monitors. Questionnaires rely on the subject's recollection of activities and allow categorization of patients by physical activity (very active, active, sedentary and inactive) [6], but may lack the precision needed to detect changes in physical activity on a day to day basis.

Daily physical activity can be expressed as an overall measure of active energy expenditure, using indirect calorimetry techniques such as doubly labelled water or metabolic carts. Although doubly labelled water is regarded as a criterion method, this technique does not quantify the duration, frequency and intensity of physical activity performed. Metabolic cart systems which measure expired $\mathrm{O}_{2}$ and $\mathrm{CO}_{2}$ however cannot be used over extended periods of time.

Physical activity can also be monitored directly using physical activity monitors. In general, three classes of

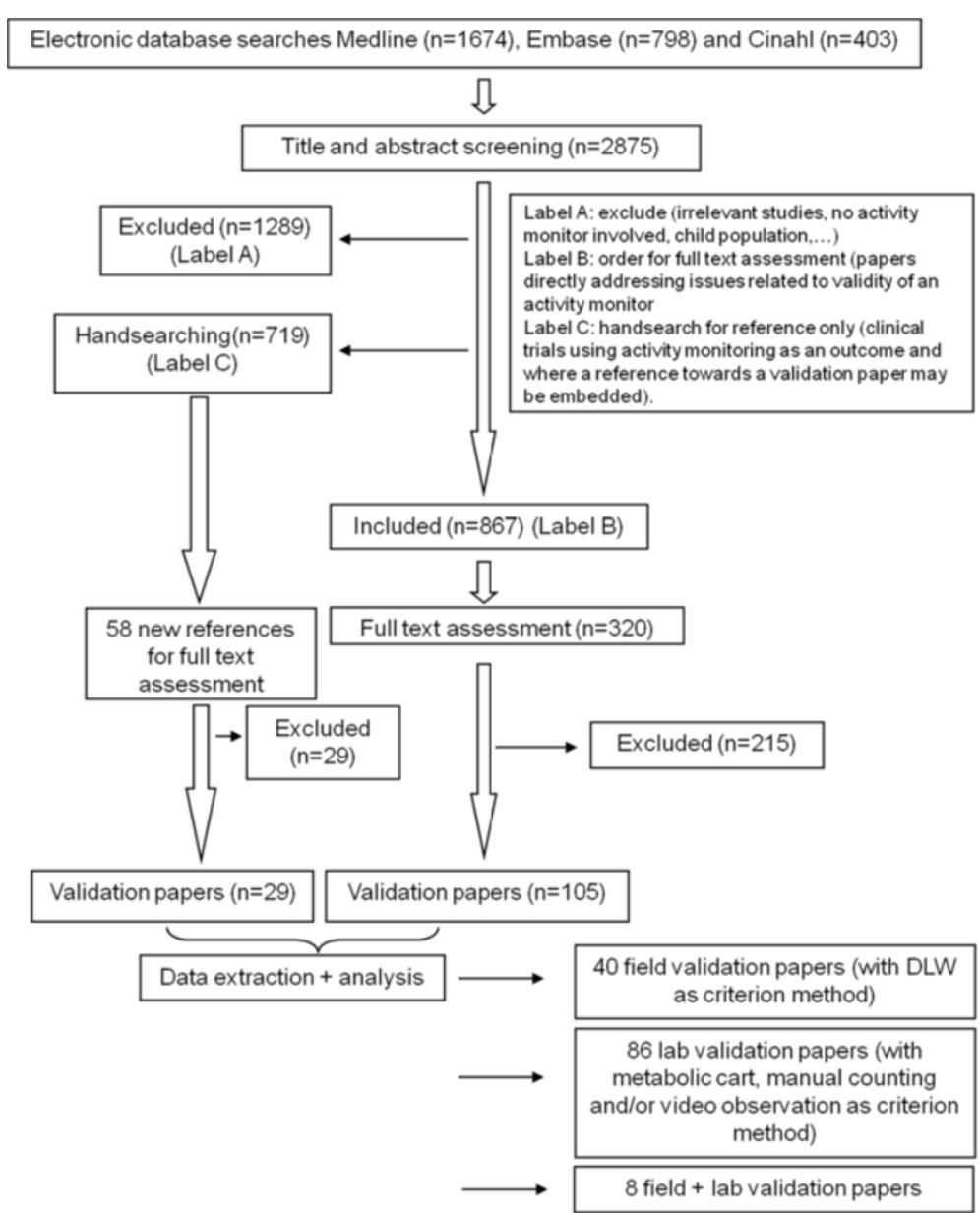

Figure 1 Flow chart describing the identification and inclusion of relevant studies. 
Table 1 Overview uniaxial activity monitors used in validation papers

\begin{tabular}{|c|c|c|c|c|c|c|c|c|c|}
\hline Name & Manufacturer & $\begin{array}{l}\text { Field(F)/Lab }(L)+ \\
\text { reference }\end{array}$ & $\begin{array}{c}\text { Size } \\
\text { (and weight) }\end{array}$ & Placement & Cost & Epoch length & Data storage & Outcomes (measured) & Outcomes (calculated) \\
\hline $\begin{array}{l}\text { Actigraph Model } \\
7164 \text { (formerly } \\
\text { CSA, MTI) }\end{array}$ & $\begin{array}{l}\text { Actigraph LLC } \\
\text { Pensacola, FL }\end{array}$ & $\begin{array}{l}F[14-24]+ \\
L[7,25-47]\end{array}$ & $\begin{array}{c}5.1 \times 4.1 \times \\
1.5 \mathrm{~cm}(45.5 \mathrm{~g})\end{array}$ & $\begin{array}{l}\text { hip, ankle } \\
\text { or wrist }\end{array}$ & NA & $5 \mathrm{~s}$ to $1 \mathrm{~min}$. & $\begin{array}{c}22 \text { days } \\
\text { (1 min epochs) }\end{array}$ & AC, steps & $\mathrm{EE}$, activity intensity level \\
\hline $\begin{array}{l}\text { Actigraph Model } \\
\text { GT1M }\end{array}$ & $\begin{array}{l}\text { Actigraph LLC } \\
\text { Pensacola, FL }\end{array}$ & $\begin{array}{l}F[48-50]+ \\
L[29,49,51-57]\end{array}$ & $\begin{array}{c}3.8 \times 3.7 x \\
1.8 \mathrm{~cm}(27 \mathrm{~g})\end{array}$ & $\begin{array}{l}\text { hip, ankle } \\
\text { or wrist }\end{array}$ & $\begin{array}{c}€ 239 \text { (unit), } \\
€ 249 \text { (software) }\end{array}$ & $\begin{array}{l}1 \mathrm{~s} \text { to several } \\
\text { minutes }\end{array}$ & $\begin{array}{c}378 \text { days } \\
\text { (1 min epochs) }\end{array}$ & AC, steps & $\mathrm{EE}$, activity intensity level \\
\hline Caltrac & $\begin{array}{l}\text { Muscle Dynamics } \\
\text { Fitness Network, } \\
\text { Torrance, USA }\end{array}$ & $\begin{array}{c}F[58-62]+ \\
L[7,34,35,63-65]\end{array}$ & $7 \times 7 \times 2 \mathrm{~cm}$ & waist & $€ 71$ (unit) & NA & no data storage & $A C$ & EE \\
\hline $\begin{array}{c}\text { Kenz Lifecorder } \\
\text { EX }\end{array}$ & $\begin{array}{l}\text { Suzuken Co Ltd., } \\
\text { Nagoya, Japan }\end{array}$ & $\begin{array}{l}F[66,67]+ \\
L[51,68-70]\end{array}$ & $\begin{array}{c}7.25 \times 4.15 \mathrm{x} \\
2.75 \mathrm{~cm}(40 \mathrm{~g})\end{array}$ & waist & $\begin{array}{l}€ 49 \text { (unit) + } \\
€ 250 \text { (software) }\end{array}$ & $5 \mathrm{~s}$ to $10 \mathrm{~min}$ & 200 days & Steps, activity level & $\mathrm{EE}$, activity intensity level \\
\hline $\begin{array}{l}\text { Calorie Counter } \\
\text { Select II }\end{array}$ & $\begin{array}{l}\text { Suzuken Co Ltd., } \\
\text { Nagoya, Japan }\end{array}$ & $L[7,71]$ & $5 \times 3 \times 1 \mathrm{~cm}$ & waist & NA & 1 day & 7 days & steps & EE \\
\hline ActivPAL & $\begin{array}{l}\text { PAL Technologies } \\
\text { Ltd, Glasgow, UK }\end{array}$ & L [57,72-74] & $\begin{array}{c}5 \times 3,5 \times \\
0,7 \mathrm{~cm}(15 \mathrm{~g})\end{array}$ & $\begin{array}{l}\text { midline on the } \\
\text { anterior aspect } \\
\text { of the thigh }\end{array}$ & NA & $1 \mathrm{~s}$ to $1 \mathrm{~min}$ & 10 days & $\begin{array}{l}\text { Steps (cadence), } \\
\text { different body positions, } \\
\text { activity score }\end{array}$ & \\
\hline PALlite & $\begin{array}{l}\text { PAL Technologies } \\
\text { Ltd, Glasgow, UK }\end{array}$ & L [74] & $\begin{array}{c}5 \times 3.5 \times \\
0.7 \mathrm{~cm}(20 \mathrm{~g})\end{array}$ & ankle & $€ 239$ & $1 \mathrm{~s}$ to $1 \mathrm{~min}$ & 10 days & Steps & \\
\hline $\begin{array}{l}\text { PAM model } \\
\text { AM101B.V. }\end{array}$ & $\begin{array}{l}\text { Doorwerth, } \\
\text { Netherlands }\end{array}$ & L [37] & $\begin{array}{c}5.8 \times 4.2 \times \\
1.3 \mathrm{~cm}(28 \mathrm{~g})\end{array}$ & waist & NA & $1 \mathrm{~s}$ to $1 \mathrm{~min}$. & 3 months & PAM scores & \\
\hline Actiwatch & $\begin{array}{l}\text { Mini Mitter Co, } \\
\text { Sunriver, OR, USA }\end{array}$ & L [75] & $\begin{array}{c}4.4 \times 2.3 \times \\
1 \mathrm{~cm}(16.1 \mathrm{~g})\end{array}$ & wrist & $\begin{array}{l}€ 713 \text { (unit), } \\
€ 213 \text { (reader) }\end{array}$ & $15 \mathrm{~s}$ to $1 \mathrm{~min}$ & $\begin{array}{c}30 \text { days } \\
\text { (1 min epochs) }\end{array}$ & $A C$ & \\
\hline Biotrainer & $\begin{array}{l}\text { IM Systems, } \\
\text { Baltimore, MD, USA }\end{array}$ & $L[41,64,76]$ & $\begin{array}{c}7 \times 7 \times \\
2 \mathrm{~cm}(51.1 \mathrm{~g})\end{array}$ & hip & NA & NA & 9 days & $A C$ & EE \\
\hline $\begin{array}{l}\text { Nike and } \\
\text { iPod sensor }\end{array}$ & $\begin{array}{c}\text { Apple Inc, } \\
\text { Cupertino, CA, USA }\end{array}$ & L [77] & $\begin{array}{c}2,4 \times 3,5 \times \\
0,8 \mathrm{~cm}(9 \mathrm{~g})\end{array}$ & shoe & $€ 19$ (sensor) & NA & $16 \mathrm{~GB}$ & Ground contact time & Distance, speed, EE \\
\hline $\begin{array}{l}\text { Polar Activity } \\
\text { Watch } 200\end{array}$ & $\begin{array}{l}\text { Polar Electro Oy, } \\
\text { Kempele, Finland }\end{array}$ & L [78] & NA & wrist & $\begin{array}{c}€ 152 \\
\text { (watch + software) }\end{array}$ & $1 \mathrm{~min}$ & Up to 9 files & Steps, HR & $\mathrm{EE}$, activity intensity level \\
\hline
\end{tabular}

Field study $(F)$, lab study $(L)$ or field + lab study $(F+L)$. PAM; physical activity monitor, $A C$; activity counts, $H R$; heart rate, $E C G$; electrocardiogram, $E E$; energy expenditure, $N A$; not available, $H R$; heart rate. 
activity monitors are being used increasingly in chronic disease populations (e.g. COPD): pedometers, accelerometers and integrated multisensor systems. Pedometers are devices which estimate the number of steps taken through mechanical or digital measurements in only the vertical plane. This is a limited measure of physical activity $[7,8]$. Accelerometers detect acceleration in one, two or three directions (uni-, bi- or triaxial accelerometers). These devices allow determination of the quantity and intensity of movements [9]. Integrated multisensor systems combine accelerometry with other sensors that capture body responses to exercise (e.g. heart rate or skin temperature) in an attempt to optimise physical activity assessments.

With the advancement of technology, the number of activity monitors available to measure physical activity is growing. However, despite these advances, it remains a challenge to assess physical activity in slowly moving patients (such as those with COPD, chronic heart failure and diabetes type II) [10-12]. In these patients small changes in physical activity are likely to be important effects of interventions aimed at enhancing physical activity. Therefore, in order for investigators to interpret the effect of interventions on physical activity, activity monitors that have been properly validated in these patient groups are needed.

In order to make evidence based statements on the validity of activity monitors, a systematic review was conducted to identify available activity monitors that have been validated in both healthy adults and chronic disease populations.

\section{Methods}

\section{Inclusion criteria}

Studies meeting the following criteria were included: (1) Population: healthy adults and adults with a diagnosis of chronic disease in whom inactivity is a likely contributor to morbidity or a target for treatment, but whose locomotor function is relatively preserved (COPD, heart failure, diabetes type II, frail elderly, primary pulmonary hypertension, chronic low back pain, fibromyalgia syndrome, obesity). (2) Measurement: any commercially available activity monitor for outdoor activity monitoring from uniaxial to triaxial accelerometers and multisensor devices to tools incorporating spatial information (e.g. GPS) or other information on motion. (3) Study design: studies that evaluated the validity of an activity monitor, i.e. testing an activity monitor against a criterion method, such as indirect calorimetry. Two types of validation studies were included; field validation studies (validation of an activity monitor against doubly labelled water) and laboratory validation studies (validation of an activity monitor using a metabolic cart or metabolic chamber and/or manual step-counting or video observation). (4) Clinical trials using activity monitoring as an outcome and which might contain a reference to a validation paper were included for hand-searching. (5) A search window between $1^{\text {st }}$ of January 2000 until $1^{\text {st }}$ of March 2012 was selected in order to capture sensors in contemporary use. This approach still allowed for the identification of older validation studies (published before 2000) of devices in current use in clinical trials. Main exclusion criteria were 1) studies in children (subjects younger than 18 years), 2) studies in subjects with abnormal biomechanical movement patterns (e.g. cerebral palsy, lower limb amputation), 3) studies only investigating the number of steps using pedometers because of the inaccuracy in measurement of total energy expenditure [7] and lack of ability to measure physical activity patterns [8].

No language restrictions were used; any non-English studies retrieved through the literature search were translated to determine their appropriateness for inclusion.

\section{Search strategy and systematic review}

Eligible studies were identified by searching the following databases: MEDLINE, EMBASE and CINAHL. A librarian was consulted prior to initiating the search in

Table 2 Overview biaxial activity monitors used in validation papers

\begin{tabular}{|c|c|c|c|c|c|c|c|c|c|}
\hline Name & Manufacturer & $\begin{array}{c}\text { Field }(F) / L a b(L)+ \\
\text { reference }\end{array}$ & $\begin{array}{c}\text { Size (I x w x h) } \\
\text { and (weight) }\end{array}$ & Placement & Cost & $\begin{array}{l}\text { Epoch } \\
\text { length }\end{array}$ & $\begin{array}{l}\text { Data } \\
\text { storage }\end{array}$ & $\begin{array}{l}\text { Outcomes } \\
\text { (measured) }\end{array}$ & $\begin{array}{c}\text { Outcomes } \\
\text { (calculated) }\end{array}$ \\
\hline $\begin{array}{l}\text { Biotrainer } \\
\text { Pro }\end{array}$ & $\begin{array}{l}\text { IM Systems, } \\
\text { Baltimore, } \\
\text { MD, USA }\end{array}$ & L [32] & $\begin{array}{l}7.6 \times 5 \times 2.2 \\
\mathrm{~cm}(51.1 \mathrm{~g})\end{array}$ & hip & $\begin{array}{l}€ 142 \text { (unit), } \\
€ 142 \text { (software), } \\
€ 70 \text { (cable) }\end{array}$ & $\begin{array}{l}15 \mathrm{~s} \text { to } \\
5 \mathrm{~min}\end{array}$ & $\begin{array}{c}22 \text { days } \\
\text { (1 min epochs) }\end{array}$ & $\begin{array}{c}\text { AC, steps, } \\
\text { activity } \\
\text { intensity level }\end{array}$ & $\mathrm{EE}$ \\
\hline Actitrac & $\begin{array}{l}\text { IM Systems, } \\
\text { Baltimore, } \\
\text { MD, USA }\end{array}$ & L [76] & $\begin{array}{c}5.6 \times 3.8 \times 1.3 \\
\mathrm{~cm}(34 \mathrm{~g})\end{array}$ & wrist & $\begin{array}{l}€ 570 \text { (unit), } \\
€ 285 \text { (software), } \\
€ 70 \text { (cable) }\end{array}$ & $\begin{array}{l}2 \mathrm{~s} \text { to } \\
2 \mathrm{~min}\end{array}$ & $\begin{array}{c}44 \text { days } \\
\text { (1 min epochs) }\end{array}$ & $A C$ & \\
\hline AMP-331 & $\begin{array}{c}\text { Activity Monitoring } \\
\text { Pod, Dynastream } \\
\text { Innovations Inc., } \\
\text { Cochrane, } \\
\text { AB, Canada }\end{array}$ & L $[26,38]$ & $\begin{array}{c}7,13 \times 2,4 \mathrm{x} \\
3,75 \mathrm{~cm}(50 \mathrm{~g})\end{array}$ & $\begin{array}{l}\text { right ankle } \\
\text { (directly } \\
\text { over the } \\
\text { Achilles } \\
\text { tendon) }\end{array}$ & NA & $\begin{array}{l}1 \text { min } \\
\text { epochs }\end{array}$ & $\begin{array}{c}28 \text { hours } \\
\text { (1 min epochs), } \\
3.5 \text { days } \\
\text { (3 min epochs) }\end{array}$ & $\begin{array}{l}\text { steps, cadence, } \\
\text { walking speed, } \\
\text { stride length, } \\
\text { distance }\end{array}$ & $\mathrm{EE}$ \\
\hline
\end{tabular}


Table 3 Overview triaxial activity monitors used in validation papers

\begin{tabular}{|c|c|c|c|c|c|c|c|c|c|}
\hline Name & Manufacturer & $\begin{array}{l}\text { Field(F)/Lab(L) } \\
\text { + reference }\end{array}$ & $\begin{array}{l}\text { Size }(I \times w \times h) \\
\text { and (weight) }\end{array}$ & Placement & Cost & $\begin{array}{l}\text { Epoch } \\
\text { length }\end{array}$ & $\begin{array}{l}\text { Data } \\
\text { storage }\end{array}$ & $\begin{array}{l}\text { Outcomes } \\
\text { (measured) }\end{array}$ & $\begin{array}{l}\text { Outcomes } \\
\text { (calculated) }\end{array}$ \\
\hline Actigraph GT3x & $\begin{array}{l}\text { Actigraph LLC } \\
\text { Pensacola, FL }\end{array}$ & L [79] & $\begin{array}{c}4.6 \times 3.3 \mathrm{x} \\
1.5 \mathrm{~cm}(19 \mathrm{~g})\end{array}$ & $\begin{array}{l}\text { Hp, ankle } € \\
\text { or wrist }\end{array}$ & $\begin{array}{l}\text { €936 (device } \\
\text { + software) }\end{array}$ & $\begin{array}{l}1 \mathrm{~s} \text { to } \\
1 \mathrm{~min}\end{array}$ & 19 days & VMU, steps & $\begin{array}{c}\text { EE, activity } \\
\text { intensity } \\
\text { level }\end{array}$ \\
\hline $\begin{array}{l}\text { RT3- Research } \\
\text { Tracker }\end{array}$ & $\begin{array}{l}\text { Stayhealthy Inc. } \\
\text { Monrovia, CA }\end{array}$ & $\begin{array}{c}\mathrm{F}[80,81]+\mathrm{L} \\
{[32,38,54,55,} \\
80,82,83]\end{array}$ & $\begin{array}{c}7.1 \times 5.6 \mathrm{x} \\
2.8 \mathrm{~cm}(65.2 \mathrm{~g})\end{array}$ & hip or waist & $\begin{array}{c}€ 142 \text { per } \\
\text { unit, } € 214 \\
\text { for docking } \\
\text { station }\end{array}$ & $\begin{array}{l}1 \mathrm{~s} \text { to } \\
1 \mathrm{~min}\end{array}$ & 21 days & $\mathrm{AC}, \mathrm{VMU}$ & $\mathrm{EE}$ \\
\hline TriTrac R3D & $\begin{array}{l}\text { Hemokinetics Inc, } \\
\text { Madison, WI }\end{array}$ & $\begin{array}{l}F[14,16,80]+ \\
L[31-33,41,63, \\
75,80,82,84-86]\end{array}$ & $\begin{array}{c}10.8 \times 6.8 \mathrm{x} \\
3.3 \mathrm{~cm}(170.4 \mathrm{~g})\end{array}$ & waist & $\$ 500$ & $1 \mathrm{~min}$ & 14 days & $A C, V M U$ & $\mathrm{EE}$ \\
\hline Tracmor & $\begin{array}{l}\text { Philips Research, } \\
\text { Eindhoven, The } \\
\text { Netherlands }\end{array}$ & $\begin{array}{c}F[87-94]+ \\
L[95-97]\end{array}$ & $\begin{array}{c}7.2 \times 2.6 \mathrm{x} \\
0.8 \mathrm{~cm}(22 \mathrm{~g})\end{array}$ & waist & $\begin{array}{c}€ 142 \text { per } \\
\text { unit, } € 214 \\
\text { for docking } \\
\text { station }\end{array}$ & NA & 21 days & $A C$ & $\mathrm{EE}$ \\
\hline $\begin{array}{c}\text { Tracmor }_{D} \text { (Philips } \\
\text { DirectLife) }\end{array}$ & $\begin{array}{l}\text { Philips New } \\
\text { Wellness Solutions }\end{array}$ & $F[98]$ & $\begin{array}{c}3,2 \times 3,2 \times \\
0,5 \mathrm{~cm}(12,5 \mathrm{~g})\end{array}$ & Lower back & $€ 113$ & NA & 22 weeks & $A C$ & $\mathrm{EE}$ \\
\hline $\begin{array}{l}\text { Dynaport activity } \\
\text { monitor }\end{array}$ & $\begin{array}{l}\text { McRoberts BV, } \\
\text { The Hague, The } \\
\text { Netherlands }\end{array}$ & $F[99]$ & $\begin{array}{l}12.5 \times 9.5 \mathrm{x} \\
3 \mathrm{~cm}(375 \mathrm{~g})\end{array}$ & $\begin{array}{l}\text { waist + one } \\
\text { leg sensor } \\
\text { (thigh) }\end{array}$ & $\begin{array}{c}€ 4900 \\
\text { (+software) }\end{array}$ & $\begin{array}{l}1 \mathrm{~s} \text { to } \\
1 \mathrm{~min}\end{array}$ & $\begin{array}{l}2 \text { days } \\
\text { (continuously) } \\
\text { More days if } \\
\text { SD memory } \\
\text { card is used }\end{array}$ & $\begin{array}{l}\text { movement } \\
\text { y) intensity, } \\
\text { different } \\
\text { body } \\
\text { positions }\end{array}$ & \\
\hline $\begin{array}{l}\text { Dynaport } \\
\text { minimod }\end{array}$ & $\begin{array}{l}\text { McRoberts BV, } \\
\text { The Hague, The } \\
\text { Netherlands }\end{array}$ & L $[100,101]$ & $\begin{array}{c}8.5 \times 5 \times \\
1 \mathrm{~cm}(70 \mathrm{~g})\end{array}$ & waist & $€ 1500$ (unit) & $\begin{array}{l}1 \mathrm{~s} \text { to } \\
1 \mathrm{~min}\end{array}$ & 7 days & $\begin{array}{l}\text { movement } \\
\text { intensity, } \\
\text { different } \\
\text { body } \\
\text { positions, } \\
\text { steps }\end{array}$ & $\mathrm{EE}$ \\
\hline Biotel $3 \mathrm{dNx}$ & $\begin{array}{l}\text { Biotel Ltd, } \\
\text { Bristol, UK }\end{array}$ & $\begin{array}{l}F[102]+ \\
L[29,103]\end{array}$ & $\begin{array}{c}12.5 \times 5.8 \times \\
0.8 \mathrm{~cm}\end{array}$ & hip or waist & $€ 800$ & $5 \mathrm{~s}$ to $60 \mathrm{~s}$ & 700 days & VMU & $\mathrm{EE}$ \\
\hline $\begin{array}{l}\text { Actimarker, } \\
\text { EW4800P }\end{array}$ & $\begin{array}{l}\text { Panasonic Electric } \\
\text { Works Co Ltd, } \\
\text { Osaka, Japan }\end{array}$ & $F[67]$ & $\begin{array}{c}6 \times 3.5 \times \\
1.3 \mathrm{~cm}(24 \mathrm{~g})\end{array}$ & waist & $€ 86$ (device) & $1 \mathrm{~min}$ & 180 days & VMU & $\mathrm{EE}$ \\
\hline ActivTracer & $\begin{array}{l}\text { GMS, Tokyo, } \\
\text { Japan }\end{array}$ & L [104] & $\begin{array}{c}4.8 \times 6.7 \mathrm{x} \\
1.6 \mathrm{~cm}(57 \mathrm{~g})\end{array}$ & waist & & & & VMU & $\begin{array}{l}\text { EE, activity } \\
\text { intensity } \\
\text { level }\end{array}$ \\
\hline Actical & $\begin{array}{l}\text { Mini Mitter Co, } \\
\text { Sunriver, OR, USA }\end{array}$ & $\begin{array}{l}\quad F[105]+ \\
L[26,38,44, \\
54,106-112]\end{array}$ & $\begin{array}{c}2.8 \times 2.7 \times \\
1.0 \mathrm{~cm}(17.5 \mathrm{~g})\end{array}$ & $\begin{array}{l}\text { hip, ankle } \\
\text { or wrist }\end{array}$ & $\begin{array}{l}€ 678 \text { (incl. } \\
\text { software)/ } \\
€ 321 \text { (unit) }\end{array}$ & $\begin{array}{l}15 \mathrm{~s} \text { to } \\
1 \mathrm{~min} \text {. }\end{array}$ & $\begin{array}{l}45 \text { days } \\
\text { ( } 1 \text { min } \\
\text { epochs) }\end{array}$ & AC, steps & $\begin{array}{l}\text { EE, activity } \\
\text { intensity } \\
\text { level }\end{array}$ \\
\hline $\begin{array}{l}\text { e-AR (earworn } \\
\text { activity } \\
\text { recognition } \\
\text { sensor) }\end{array}$ & $\begin{array}{l}\text { Sensixa Ltd, } \\
\text { London, UK }\end{array}$ & L [113] & $\begin{array}{c}5,6 \times 3,5 \times \\
1,0 \mathrm{~cm}(7.4 \mathrm{~g})\end{array}$ & ear & NA & $1 \mathrm{~min}$ & NA & $A C$ & $\mathrm{EE}$ \\
\hline $\begin{array}{l}\text { PASE (Physical } \\
\text { Activity Sensing } \\
\text { Earpiece) }\end{array}$ & $\begin{array}{l}\text { MMA7260Q, } \\
\text { Freescale } \\
\text { Semiconductor, } \\
\text { Austin, Texas }\end{array}$ & L [114] & $\begin{array}{c}0,6 \times 0,6 \times \\
0,14 \mathrm{~cm}(40 \mathrm{~g} \\
\text { including data } \\
\text { logging system) }\end{array}$ & ear & NA & $\begin{array}{l}15 \mathrm{~s} \text { to } \\
1 \mathrm{~min} \text {. }\end{array}$ & NA & $\begin{array}{c}\text { Acceleration } \\
\text { units }\end{array}$ & $\begin{array}{c}\text { EE, activity } \\
\text { intensity } \\
\text { level }\end{array}$ \\
\hline GENEA & $\begin{array}{c}\text { Unilever Discovery, } \\
\text { Sharnbrook } \\
\text { Bedfordshire, UK }\end{array}$ & $\begin{array}{c}F[115]+ \\
L[55]\end{array}$ & $\begin{array}{c}3,6 \times 3,0 \times \\
1,2 \mathrm{~cm}(16 \mathrm{~g})\end{array}$ & $\begin{array}{l}\text { Wrist, waist, } \\
\text { ankle }\end{array}$ & NA & NA & 8 days & VMU & $\mathrm{EE}$ \\
\hline $\begin{array}{l}\text { Activity Style } \\
\text { Pro HJA-350IT }\end{array}$ & $\begin{array}{c}\text { Omron Healthcare, } \\
\text { Kyoto, Japan }\end{array}$ & L [116] & $\begin{array}{c}7.4 \times 4.6 \mathrm{x} \\
3.4 \mathrm{~cm}(60 \mathrm{~g})\end{array}$ & waist & NA & NA & NA & VMU & $\begin{array}{c}\text { Activity } \\
\text { intensity level }\end{array}$ \\
\hline $\begin{array}{l}\text { CAM (Continuous } \\
\text { Activity Monitor) }\end{array}$ & $\begin{array}{c}\text { Maastricht } \\
\text { Instruments B.V. }\end{array}$ & L [117] & $6.3 \times 4.5 \times 1.8(102 \mathrm{~g})$ & leg & NA & NA & NA & VMU & $\begin{array}{c}\text { Activity } \\
\text { intensity level, } \\
\text { Different body } \\
\text { positions }\end{array}$ \\
\hline
\end{tabular}


Table 4 Overview multisensor activity monitors used in validation papers

\begin{tabular}{|c|c|c|c|c|c|c|c|c|c|}
\hline Name & Manufacturer & $\begin{array}{l}\text { Field(F)/Lab }(\mathrm{L}) \\
\text { + reference }\end{array}$ & $\begin{array}{l}\text { Size (I } \times \text { w } \times \text { h) } \\
\text { and (weight) }\end{array}$ & Placement & Cost & $\begin{array}{l}\text { Epoch } \\
\text { length }\end{array}$ & $\begin{array}{l}\text { Data } \\
\text { storage }\end{array}$ & $\begin{array}{l}\text { Outcomes } \\
\text { (measured) }\end{array}$ & $\begin{array}{l}\text { Outcomes } \\
\text { (calculated) }\end{array}$ \\
\hline $\begin{array}{l}\text { PAMS (Physical Activity } \\
\text { Monitoring System) }\end{array}$ & $\begin{array}{l}\text { ICSensors 3031-010, Druck, } \\
\text { The Netherlands }\end{array}$ & L [118] & $\begin{array}{c}5,0 \times 3,0 \times 0,8 \mathrm{~cm} \\
\text { (Tracmor, } 16 \mathrm{~g})+4 \text { tilt } \\
\text { sensors (total } \\
\text { weight }=1,3 \mathrm{~kg} \text { ) }\end{array}$ & $\begin{array}{l}\text { lower back (Tracmor) + } \\
\text { lateral aspect of the } \\
\text { trunk and to the lateral } \\
\text { aspect of the mid-thigh } \\
\text { (sensors) }\end{array}$ & NA & NA & NA & voltage units & $\begin{array}{c}\text { body position } \\
\text { (lying, sitting, standing) }\end{array}$ \\
\hline Actireg & Premed AS, Oslo, Norway & $\begin{array}{c}F[119,120]+ \\
L[46]\end{array}$ & $\begin{array}{c}8.5 \times 4.5 \times 1.5 \mathrm{~cm} \\
(60 \mathrm{~g})\end{array}$ & $\begin{array}{l}\text { waist (storage unit) + } \\
\text { chest and right } \\
\text { thigh (sensors) }\end{array}$ & $\begin{array}{c}€ 440 \\
\text { (device) }+ \\
€ 380 \\
\text { (software) }\end{array}$ & $\begin{array}{r}1 \mathrm{~s} \text { to } \\
+1 \mathrm{~min}\end{array}$ & 30 days & $\begin{array}{l}\text { body position } \\
\text { and movement }\end{array}$ & $\begin{array}{l}\text { Activity intensity } \\
\text { level, EE }\end{array}$ \\
\hline $\begin{array}{l}\text { Vitaport (+ } 4 \text { uniaxial } \\
\text { accelerometers (ADXL202)) }\end{array}$ & $\begin{array}{l}\text { University of Cologne, Cologne, } \\
\text { Germany (Vitaport)/Analog devices, } \\
\text { Breda, The Netherlands } \\
\text { (Uniaxial accelerometers) }\end{array}$ & L [121] & $\begin{array}{l}1.5 \times 1.5 \times 1 \mathrm{~cm} \\
\text { (uniaxial accelerometer, } \\
8 \mathrm{~g}) / 6 \times 11 \times 3 \mathrm{~cm} \\
\text { (Vitaport, data } \\
\text { recorder, } 500 \mathrm{~g} \text { ) }\end{array}$ & $\begin{array}{l}4 \text { sensors: } 2 \text { on skin } \\
\text { of the ventral side of } \\
\text { each thigh, } 2 \text { on the } \\
\text { skin of the sternum,) }\end{array}$ & $€ 15.000$ & $\begin{array}{l}1 \mathrm{~s} \text { to } \\
1 \mathrm{~min}\end{array}$ & 3 days & $\begin{array}{l}\text { acceleration } \\
\text { units }\end{array}$ & $\begin{array}{l}\text { motility legs, } \\
\text { motility trunk, } \\
\text { motility body }\end{array}$ \\
\hline $\begin{array}{l}\text { Sensewear Pro Armband } \\
\text { (formerly Healthwear Armband) }\end{array}$ & Bodymedia, Pittsburgh, PA, USA & $\begin{array}{c}F[50,122-126]+ \\
\quad[32,46,100 \\
125-138]\end{array}$ & $\begin{array}{c}8.8 \times 5.6 \times 2.1 \mathrm{~cm} \\
(82 \mathrm{~g})\end{array}$ & $\begin{array}{l}\text { Upper right arm } \\
\text { at triceps } \\
\text { (midhumerus point) }\end{array}$ & $\begin{array}{c}€ 800 \\
\text { (device) }+ \\
€ 1597 \\
\text { (software) }\end{array}$ & $1 \mathrm{~min}$ & 14 days & $\begin{array}{l}\text { Steps, activity } \\
\text { intensity level }\end{array}$ & EE \\
\hline SenseWear Mini Armband & Bodymedia, Pittsburgh, PA, USA & $F[124]$ & NA & $\begin{array}{l}\text { Upper left arm } \\
\text { at triceps } \\
\text { (midhumerus point) }\end{array}$ & $\begin{array}{l}€ 722 \\
\text { (device) }+ \\
€ 1597 \\
\text { (software) }\end{array}$ & $\begin{array}{r}1 \mathrm{~s} \text { to } \\
+1 \mathrm{~min}\end{array}$ & 28 days & $\begin{array}{l}\text { Steps, activity } \\
\text { intensity level }\end{array}$ & EE \\
\hline Actiheart & Mini Mitter Sunriver, OR, USA & $L[29,108,139]$ & $\begin{array}{l}0.5 \times 1.1 \times 2.2 \mathrm{~cm}(\mathrm{clip})+ \\
10 \mathrm{~cm} \text { (wire) }(10 \mathrm{~g})\end{array}$ & $\begin{array}{l}\text { 3th intercostals } \\
\text { space (clip) + } 2 \text { ECG } \\
\text { electrodes (chest) }\end{array}$ & $€ 1330$ & $\begin{array}{l}15 \mathrm{~s} \text { to } \\
1 \mathrm{~min}\end{array}$ & $\begin{array}{l}11 \text { days } A \\
(1 \mathrm{~min} \\
\text { epochs) }\end{array}$ & $\begin{array}{l}\text { Acceleration HR, } \\
\text { HR variability, } \\
\text { ECG amplitude }\end{array}$ & EE \\
\hline Ikcal & Teltronic AG, Biberist, Switzerland & $L[46]$ & NA & $\begin{array}{l}\text { Chest (elastic belt } \\
\text { around the sternum) }\end{array}$ & NA & NA & NA & Acceleration, HR & EE \\
\hline Multi-sensor board & $\begin{array}{l}\text { Department of Epidemiology, } \\
\text { University of Washington, USA }\end{array}$ & L [111] & $25 \mathrm{~g}$ & Hip & NA & $\begin{array}{l}1 \mathrm{~s} \text { to } \\
1 \mathrm{~min}\end{array}$ & NA & $\begin{array}{l}\text { Steps, activity } \\
\text { intensity level, } \\
\text { different body } \\
\text { positions }\end{array}$ & $\mathrm{EE}$ \\
\hline $\begin{array}{l}\text { IDEEA (Intelligent Device for } \\
\text { Energy Expenditure and Activity) }\end{array}$ & MiniSun, LLC, Fresno, CA, USA & $\begin{array}{l}\mathrm{F}[140]+ \\
\mathrm{L}[141]\end{array}$ & $\begin{array}{l}7 \times 5.4 \times 1.7 \mathrm{~cm}(59 \mathrm{~g}) \\
(\text { recorder })+1.8 \times 1.5 \times \\
0.3 \mathrm{~cm}(2 \mathrm{~g}) \text { (sensor) }\end{array}$ & $\begin{array}{l}\text { Waist (processing unit) } \\
+ \text { sole of both feet, } \\
\text { both thighs and } \\
\text { chest (sensors) }\end{array}$ & NA & $\begin{array}{l}1 \mathrm{~s} \text { to } \\
1 \mathrm{~min}\end{array}$ & 7 days & $\begin{array}{l}\text { Activity code, } \\
\text { speed, distance, } \\
\text { power output }\end{array}$ & $\mathrm{EE}$ \\
\hline
\end{tabular}


order to identify appropriate search terms to describe the population (from healthy adults to patients with chronic disease), physical activity and activity monitoring. A combination of MeSH terms (MEDLINE), Emtree terms (Embase) and Cinahl headings (Cinahl) with free text words (all databases) were used (see Additional file 1 for detailed information). Refworks (www.refworks. com) was used to store and share all papers and to collect all the information of title and abstract screening, full text assessment and the hand-searching process. Each review team consisted of 3 reviewers who independently screened the titles and abstracts of the retrieved articles. Each abstract was labelled as 'A) excluded papers', 'B) order for full text assessment'or ' $\mathrm{C}$ ) hand-search for references only', i.e. clinical trials which may have a reference to an older validation study. After independently reviewing the articles for inclusion, the reviewers compared their labels to ensure consensus. Once agreement had been reached, a full text copy of each article that met the inclusion criteria was obtained (Label B). Thereafter, the same review teams looked at the full texts of the potential validation papers in detail and decided in consensus, whether the articles were indeed suitable validation papers for data extraction. Subsequently, hand-searching of the clinical trials using an activity monitor outcome which might contain a reference to a validation paper (Label C), was performed by three independent reviewers. After independently reviewing these full texts, validation papers were identified which met the inclusion criteria for full text assessment. Again, the reviewers compared their decisions to ensure consensus. Data of all included validation papers were extracted into predefined prepared Excel tables.

\section{Data extraction}

For the field studies, correlation coefficients between total and active energy expenditure from activity monitor $\left(\mathrm{TEE}_{\mathrm{AM}}\right.$ and $\mathrm{AEE}_{\mathrm{AM}}$ respectively) and total

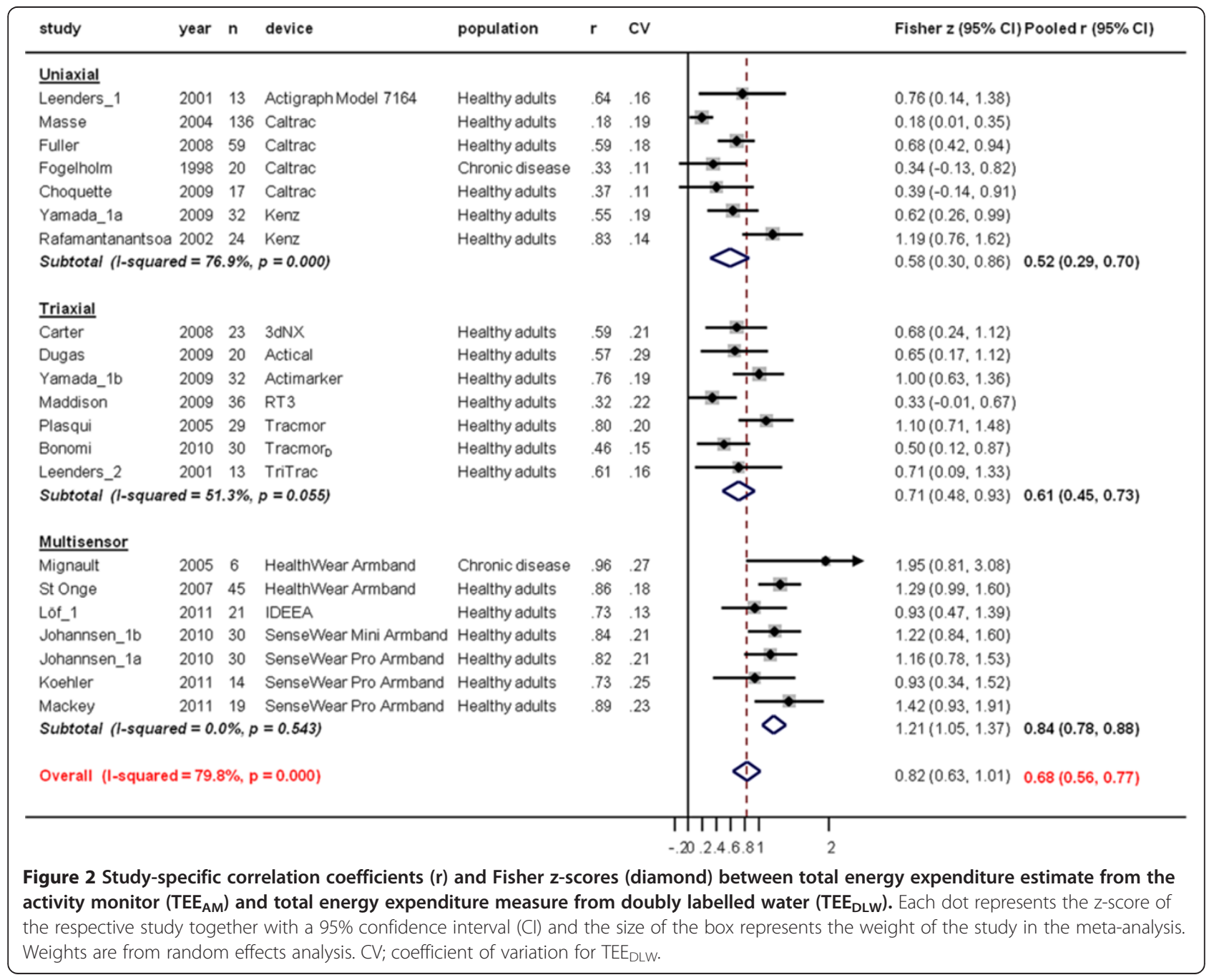


and active energy expenditure measured with doubly labelled water $\left(\mathrm{TEE}_{\mathrm{DLW}}\right.$ and $\mathrm{AEE}_{\mathrm{DLW}}$ respectively) were extracted. The percentage mean differences $(\triangle \mathrm{TEE}$ and $\triangle \mathrm{AEE})$ with $95 \%$ confidence intervals were obtained from the reports to assess agreement between energy expenditure estimates from the activity monitor $\left(\mathrm{TEE}_{\mathrm{AM}}\right.$ and $\left.\mathrm{AEE} \mathrm{AM}_{\mathrm{AM}}\right)$ versus energy expenditure measures from doubly labelled water $\left(\mathrm{TEE}_{\mathrm{DLW}}\right.$ and $\left.A E E_{D L W}\right)$. For the laboratory studies, correlation coefficients between activity monitor outcome and EE measured by metabolic cart/chamber were extracted. A subanalysis included to compare correlation coefficients derived from walking based protocols to correlation coefficients derived from protocols based on activities of daily living. Agreement between energy expenditure outcomes from the activity monitor versus criterion method (indirect calorimetry) were extracted by the mean difference at different treadmill walking speeds; slow walk $(<3.2 \mathrm{~km} / \mathrm{hr}$ or $1 \mathrm{mph})$, intermediate speed walk (3.2-6.4 $\mathrm{km} / \mathrm{hr}$ or $2-4 \mathrm{mph}$ ), fast walk (6.5-
$8.05 \mathrm{~km} / \mathrm{hr}$ or $4-5 \mathrm{mph})$ and running $(8.06-11 \mathrm{~km} / \mathrm{hr}$ or 5-7 mph). Accuracy of steps measured by activity monitoring was expressed as the percentage mean difference between steps measured by an activity monitor versus actual steps measured by the criterion method (video observation and/or manual step counting).

\section{Statistical analysis}

Descriptive statistics were used to report information about type of activity monitor, activity monitor outcomes and studied population. Papers were separated by type of validation, 'field validation papers' (validation of an activity monitor against indirect calorimetry, using the doubly labelled water technique) and 'lab validation papers' (validation of an activity monitor against indirect calorimetry, using a metabolic cart, metabolic chamber or direct observation).

We also analysed the results separately per type of device (uni-, bi-, triaxial and multisensor devices). We performed (DerSimonian and Laird) random-effects meta-

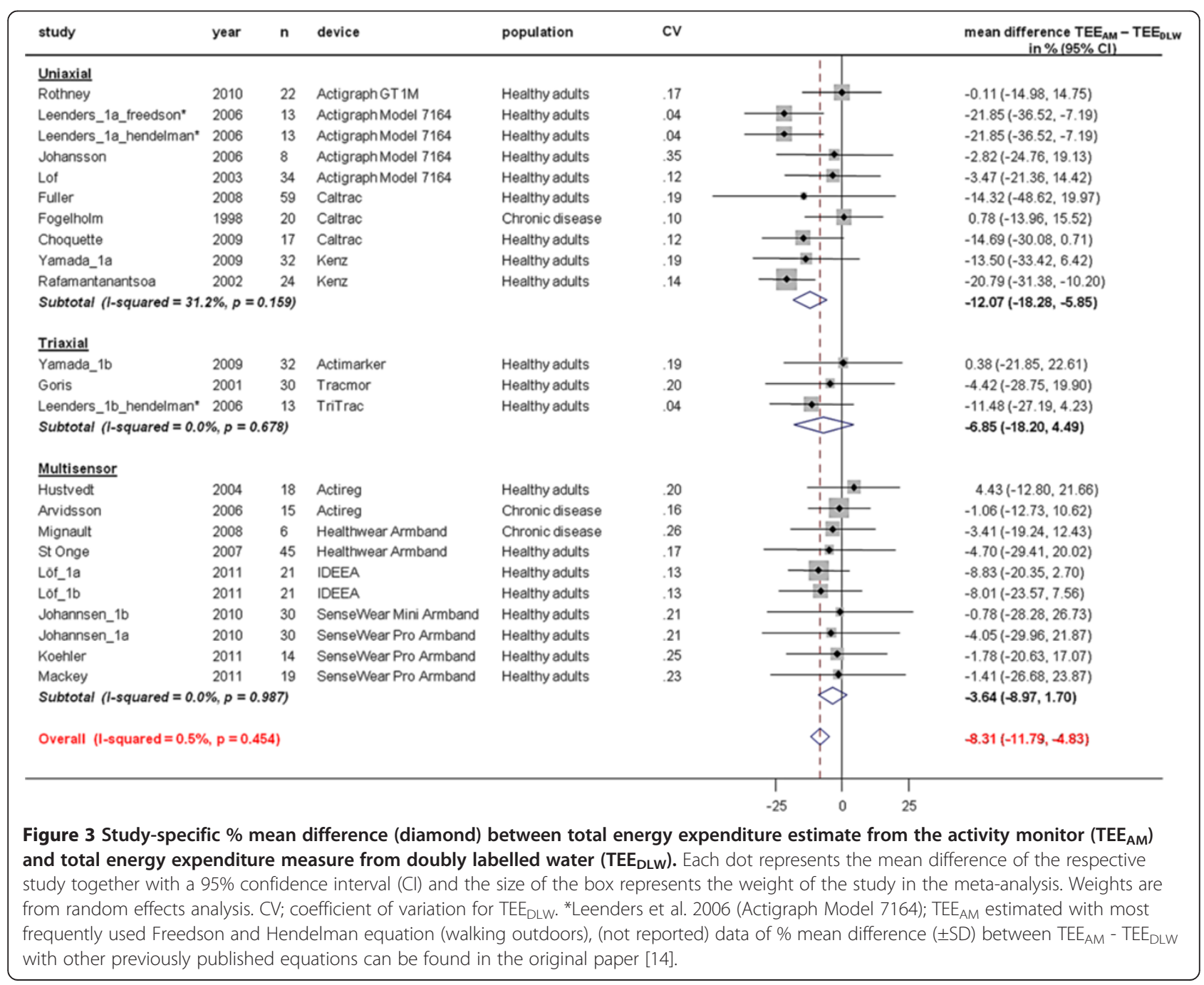


analyses to pool the correlation coefficients and mean differences across studies and expressed heterogeneity by the $\mathrm{I}^{2}$ statistic, which estimates the percentage of total variation between studies that is due to heterogeneity rather than chance. $\mathrm{I}^{2}$ is calculated from basic results obtained from a typical meta-analysis as $\mathrm{I}^{2}=100 \% \times(\mathrm{Q}-\mathrm{df}) / \mathrm{Q}$, where $\mathrm{Q}$ is Cochran's heterogeneity statistic and $\mathrm{df}$ the degrees of freedom. Negative values of $\mathrm{I}^{2}$ are put equal to zero so that $\mathrm{I}^{2}$ lies between $0 \%$ en $100 \%$ with larger values showing larger heterogeneity. We used the Fisher $r$ to $z$-transformation in order to pool normally distributed data ( $\mathrm{z}$ scores) rather than the skewed distribution of Pearson correlation coefficients [13]. We back transformed the pooled z-scores to correlation coefficients for easier interpretation.

We used random-effects linear regression models (meta-regression analyses) with the studies' results as the dependent variable (and considering each studies' standard error) to compare the type of devices (covariate) and to assess the type of population (covariate) as a potential explanation for heterogeneity. For those few studies where no measures of variability were reported we imputed the median standard deviations of those studies where the standard deviation was available. We did not perform meta-analyses for the laboratory studies where none of the studies provided standard deviations for $\triangle \mathrm{TEE}$ and $\triangle \mathrm{AEE}$ but presented the point estimates as graphs. Coefficient of variation for $T_{E E} E_{D L W}$ and $\mathrm{AEE}_{\mathrm{DLW}}$ was calculated per study population to investigate whether the degree of variation in $\mathrm{TEE}_{\mathrm{DLW}}$ and $\mathrm{AEE}_{\mathrm{DLW}}$ affected the correlation coefficients and/or mean differences, (i.e. higher correlations/mean differences in populations with larger variation in TEE and/or AEE).

\section{Results}

The systematic literature search resulted in a total of 2875 abstracts which were scrutinised by four review teams across Europe. Figure 1 represents the different processes used in the systematic review.

Forty monitors were tested in validation studies; 12 uniaxial, 3 biaxial, 16 triaxial accelerometers and 9 multisensor devices. Fifty-five percent of activity monitors $(22 / 40)$ were used only in lab validation studies, $10 \%$ (4/ 40) only in field validation studies and 35\% (14/40) in both a lab as well as a field validation study. An

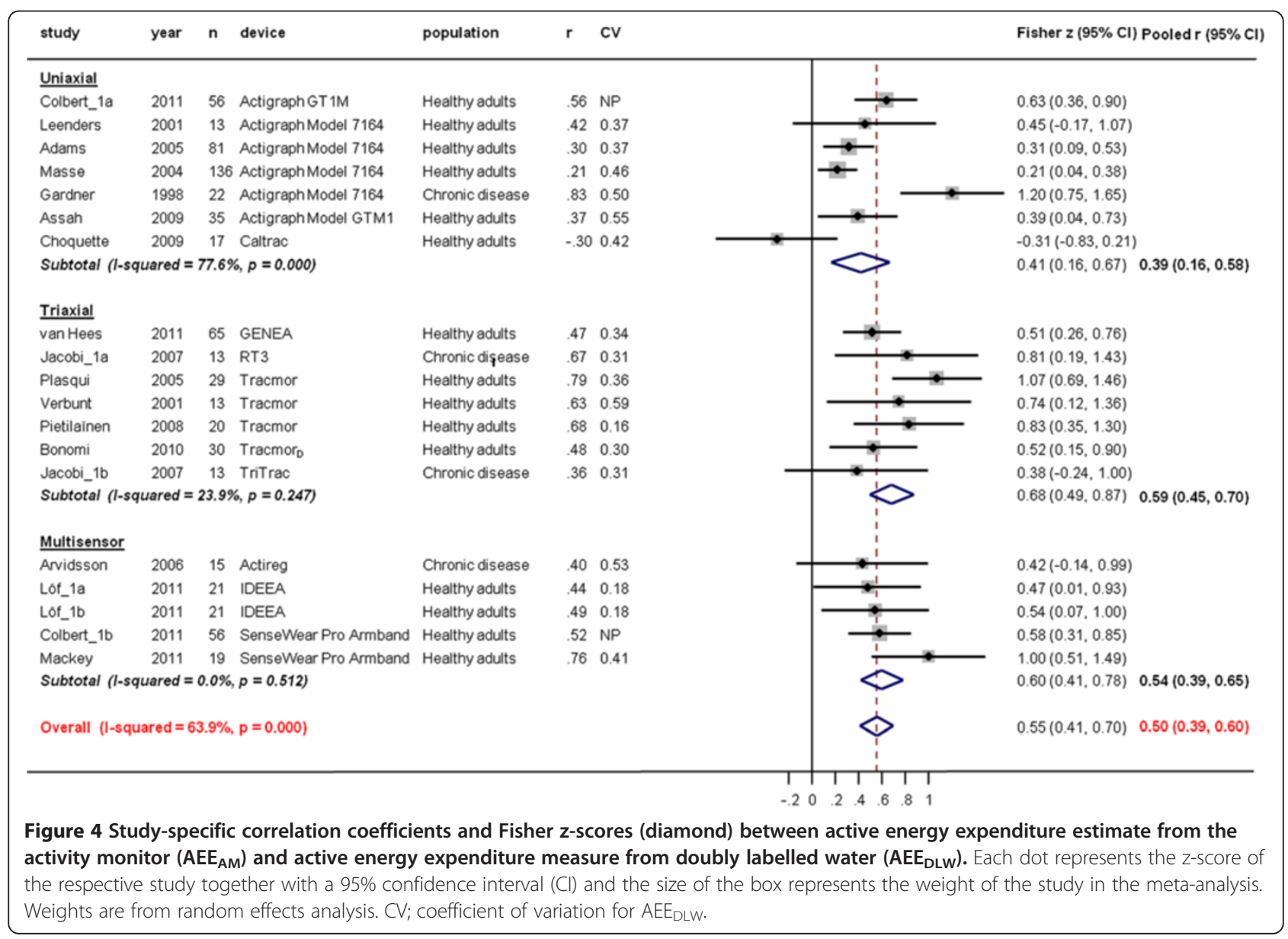


overview of the different activity monitors is shown in Tables 1, 2, 3 and 4.

The most frequently available outcomes present in validated activity monitors are (total and/or active) energy expenditure $(70 \%, 28 / 40)$, steps $(38 \%, 15 / 40)$ and different levels of physical activity intensity $(38 \%, 15 /$ $40)$. The majority of the validation studies $(118 / 134$, $88 \%)$ were performed in healthy adults. Few studies (16/ $134,12 \%)$ were performed in chronic disease populations; obesity $(\mathrm{n}=4)$, chronic obstructive pulmonary disease $(n=5)$, chronic heart failure $(n=1)$, chronic organ failure $(n=1)$, chronic low back pain $(n=1)$, fibromyalgia syndrome $(n=1)$, peripheral arterial disease $(n=1)$, diabetes mellitus type II $(n=1)$ and a general chronic disease population (cardiac, obese or knee arthritis, $\mathrm{n}=1$ ).

\section{Field validation studies}

Individual correlation coefficients, with converted Fisher z-scores, for total energy expenditure (TEE) between $\mathrm{TEE}_{\mathrm{AM}}$ and $\mathrm{TEE} \mathrm{DLW}_{\mathrm{DL}}$ are presented in Figure 2.
Variability of study populations' $\mathrm{TEE}_{\mathrm{DLW}}$ was relatively small; coefficient of variation (CV) ranged from 0.11 to 0.29 . Pooled $\mathrm{r}$ in uniaxial devices $(\mathrm{r}=0.52(95 \% \mathrm{CI}, 0.29$ to $0.70)$ ) was significantly lower compared to multisensor devices ( $\mathrm{r}=0.84$ (95\%CI, 0.78 to 0.88$), \mathrm{p}<0.001$ ) but not to triaxial devices $(\mathrm{r}=0.61(95 \% \mathrm{Cl}, 0.45$ to $0.73, \mathrm{p}=0.37))$. Because of the relatively large difference in accuracy between the uniaxial, the triaxial and multisensor devices $53 \%$ of the between-study heterogeneity was accounted for by type of device in meta-regression analyses.

$\triangle \mathrm{TEE}\left(\mathrm{TEE}_{\mathrm{AM}}-\mathrm{TEE}_{\mathrm{DLW}}\right)$ was less accurate in uniaxial compared to triaxial accelerometers and multisensor devices $(-12.07(95 \% \mathrm{CI},-18.28$ to -5.85$) \%$ in uniaxial versus $-6.85(95 \% \mathrm{CI},-18.20$ to 4.49$) \%$ in triaxial $(\mathrm{p}=0.39$ for comparison against uniaxial devices) and $-3.64(95 \% \mathrm{CI},-8.97$ to 1.70$) \%$ in multisensor devices, $\mathrm{p}=0.03$ for comparison against uniaxial devices, Figure 3). $\triangle \mathrm{TEE}$ were smaller in studies with chronic disease populations than in studies with healthy populations $(-9 \%(95 \% \mathrm{CI}-19$ to 1$))$ but the difference did not reach statistical significance $(\mathrm{p}=0.09)$.

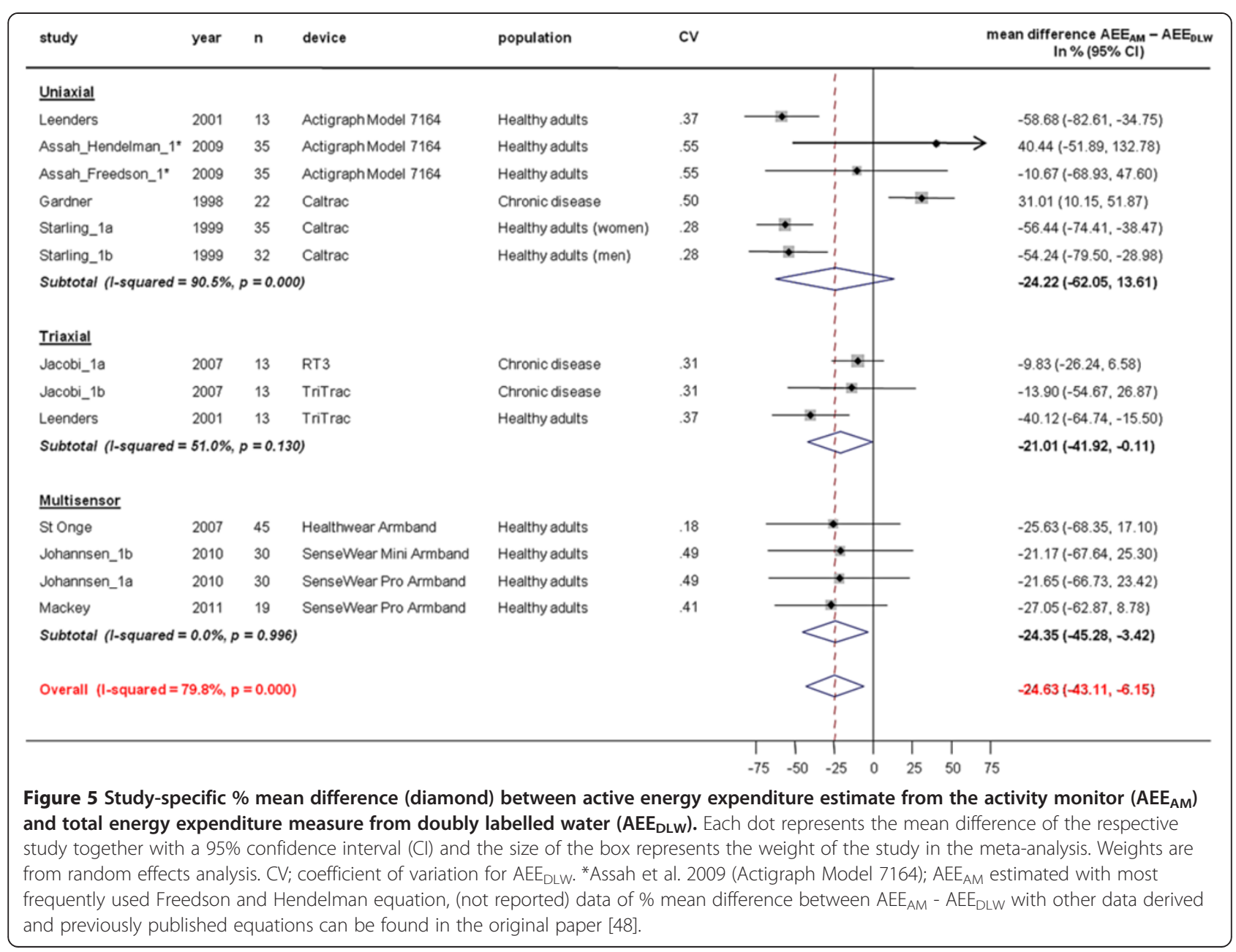




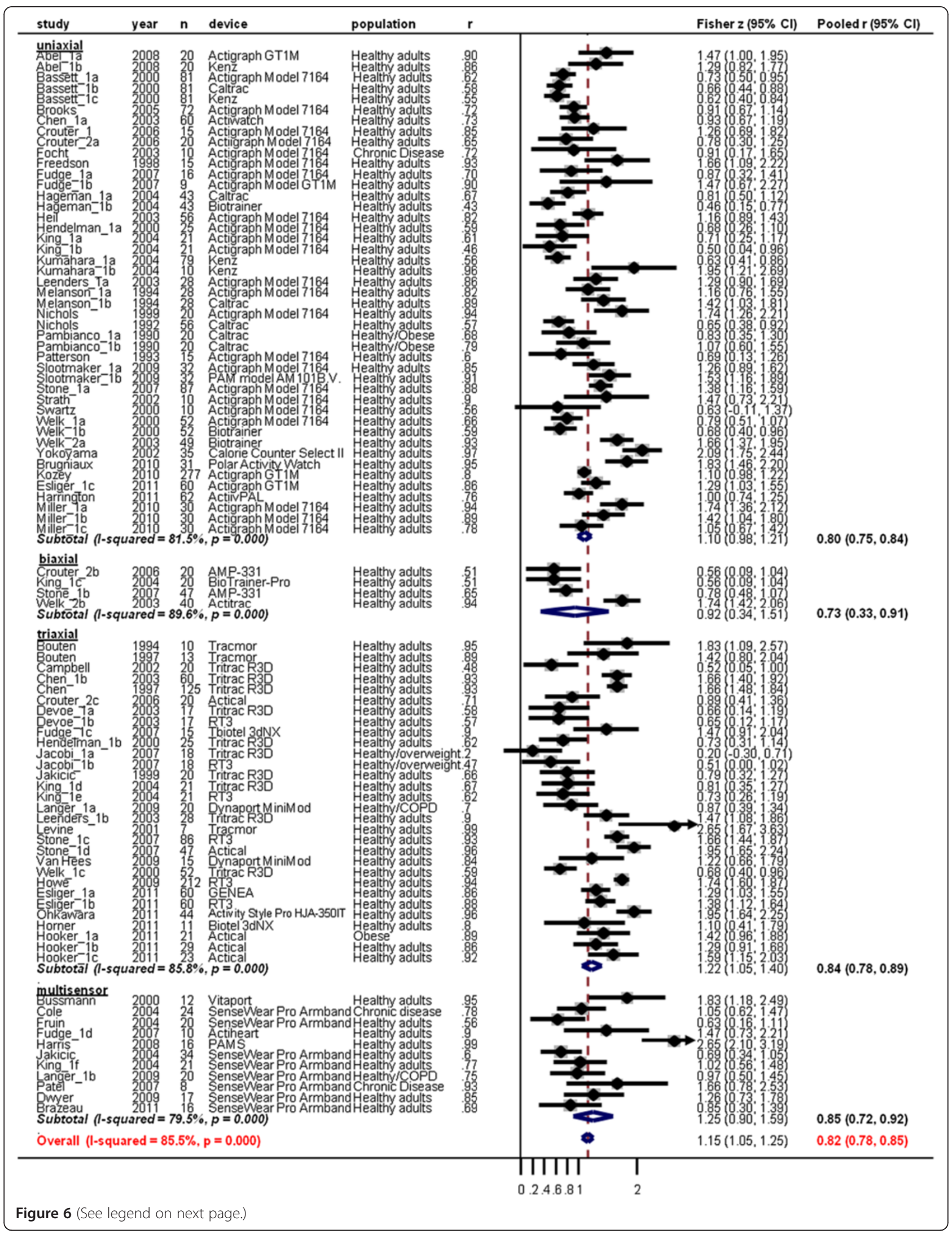


(See figure on previous page.)

Figure 6 Study-specific correlation coefficients ( $r$ ) and Fisher z-scores (diamond) between activity monitor outcomes and total energy expenditure measure from indirect calorimetry $\left(\mathrm{TEE}_{\mathrm{IC}}\right)$ during laboratory protocols. Each dot represents the $z$-score of the respective study together with a 95\% confidence interval $(\mathrm{Cl})$ and the size of the box represents the weight of the study in the meta-analysis. Weights are from random effects analysis.

Correlations for active energy expenditure (AEE) between $\mathrm{AEE}_{\mathrm{AM}}$ and $\mathrm{AEE} \mathrm{DLW}_{\mathrm{DW}}$ were higher in triaxial $(0.59$ (95\% CI, 0.45 to 0.70$)$ ) and multisensor devices $(0.54$ (95\% CI, 0.39 to 0.65$))$ compared to uniaxial $(0.39(95 \%$ $\mathrm{CI}, 0.16$ to 0.58$)$ ) devices, $\mathrm{p}=0.12$ for triaxial and $\mathrm{p}=0.32$ for multisensor against uniaxial devices) (Figure 4) Types of devices accounted for only $12 \%$ of the between-study heterogeneity in the meta-regression analysis. All monitors underestimated AEE ( $\triangle \mathrm{AEE}$ $\left(\mathrm{AEE}_{\mathrm{AM}}-\mathrm{AEE}_{\mathrm{DLW}}\right)-24.22(95 \% \mathrm{CI},-62.05$ to -13.61$) \%$ in uniaxial, $-21.01(95 \% \mathrm{CI},-41.92$ to -0.11$) \%$ in triaxial and -24.35 (95\%CI, -45.28 to -3.42$) \%$ in multisensor devices. No significant differences were found between devices (Figure 5). But $\triangle \mathrm{AEE}$ were statistically significantly smaller in studies with chronic disease populations than in studies with healthy populations $(-44 \%$, $95 \% \mathrm{CI}-73$ to $-13, \mathrm{p}=0.006$ ).

\section{Laboratory validation studies}

For correlation analysis, TEE and AEE, as determined from indirect calorimetry, were used as criterion outcomes (in $89 \%$ and $11 \%$ of the studies, respectively) against different outcomes of the activity monitor (activity counts (37\%), vector magnitude units (7\%), total energy expenditure (48\%), active energy expenditure (2\%) or monitor-specific activity scores (6\%).

Pooled correlation coefficients between indirect calorimetry $\left(\mathrm{TEE}_{\mathrm{IC}}\right)$ and activity monitor outcome were lower in uniaxial $(0.80(95 \% \mathrm{CI}, 0.75$ to 0.84$))$ compared to multisensor devices $(0.85$ (95\% CI, 0.72 to 0.92$)$ ) but the difference did not reach statistical significance $(\mathrm{p}=0.43)$ No differences were found with biaxial $(0.73$ (95\%CI, 0.33 to 0.91$), \mathrm{p}=0.50)$ and triaxial $(0.84(95 \% \mathrm{CI}, 0.78$ to 0.89 ), $\mathrm{p}=0.28$ ) devices, either (Figure 6).

Correlation coefficients between $\mathrm{TEE}_{\mathrm{IC}}$ and activity monitor outcome were higher when tested using laboratory protocols based on walking activities (overall pooled $r=0.84(95 \% \mathrm{CI}, 0.79$ to 0.87$)$, no significant differences between types of devices, Figure 7) compared to protocols using activities of daily living involving the upper and lower limbs (overall pooled $\mathrm{r}=0.75$ (95\%CI, 0.68 to 0.81 , no significant differences between types of devices), Figure 8).

There was evidence of heterogeneity of results across all analyses (overall $\mathrm{I}^{2}$ ranged from $84.6 \%$ (Figure 7 ) to $85.9 \%$ (Figure 8$)$ ). Again, the results did not differ for chronic disease and healthy populations in any of the analyses on laboratory validation studies.

Mean differences between $\mathrm{TEE}_{\mathrm{AM}}$ and $\mathrm{TEE}_{\mathrm{IC}}$ at different treadmill walking speeds are presented in Figures 9, 10, 11 and 12. TEE was underestimated during slow walking speed in $69 \%$ of studies $(n=16 / 23)$, whereas in only $37 \%$ of studies $(n=15 / 40)$ during intermediate walking speed, $30 \%$ of studies $(n=10 / 33)$ during fast walking speed and $37 \%$ of studies $(n=7 / 19)$ during running reported underestimation of TEE. Underestimations in the slow walking group were relatively larger.

All accelerometers underestimate steps during slow walking; from 0.94 to $60 \%$ underestimation. One uniaxial device (activPAL), mounted on the thigh, showed a high accuracy in measuring steps during slow walking with only $0.94 \%$ overestimation. More accurate estimates of steps were reported at higher speeds; from $13 \%$ under to $2 \%$ overestimation during intermediate walking speed (except one study with 35\% underestimation using SenseWear Armband), and from 0.18 to $4.3 \%$ overestimation during fast walking (Figure 13).

\section{Discussion}

This systematic review of the literature identified forty activity monitors (12 uniaxial, 3 biaxial, 16 triaxial and 9 multisensor devices) that had been validated against indirect calorimetry (doubly labelled water, metabolic cart and/or metabolic chamber) in healthy adults $(88 \%$ of studies) or adults with chronic disease $(12 \%$ of studies).

Field and laboratory validation studies had highly heterogeneous results which could partly be explained by the type of activity monitor and the activity monitor outcome. These factors need consideration when a validation study is evaluated.

First, selecting the type of activity monitor is important. Pedometers are limited in their ability to detect certain physical activity patterns which might occur in chronic disease populations (for example, an unstable gait profile or lack of intensity of physical activity). Accelerometers can overcome this. Multi-axial accelerometers have the ability to measure accelerations in different orientations, which provides information about the total amount, intensity and duration of daily physical activity. Some multisensor devices, which combine 


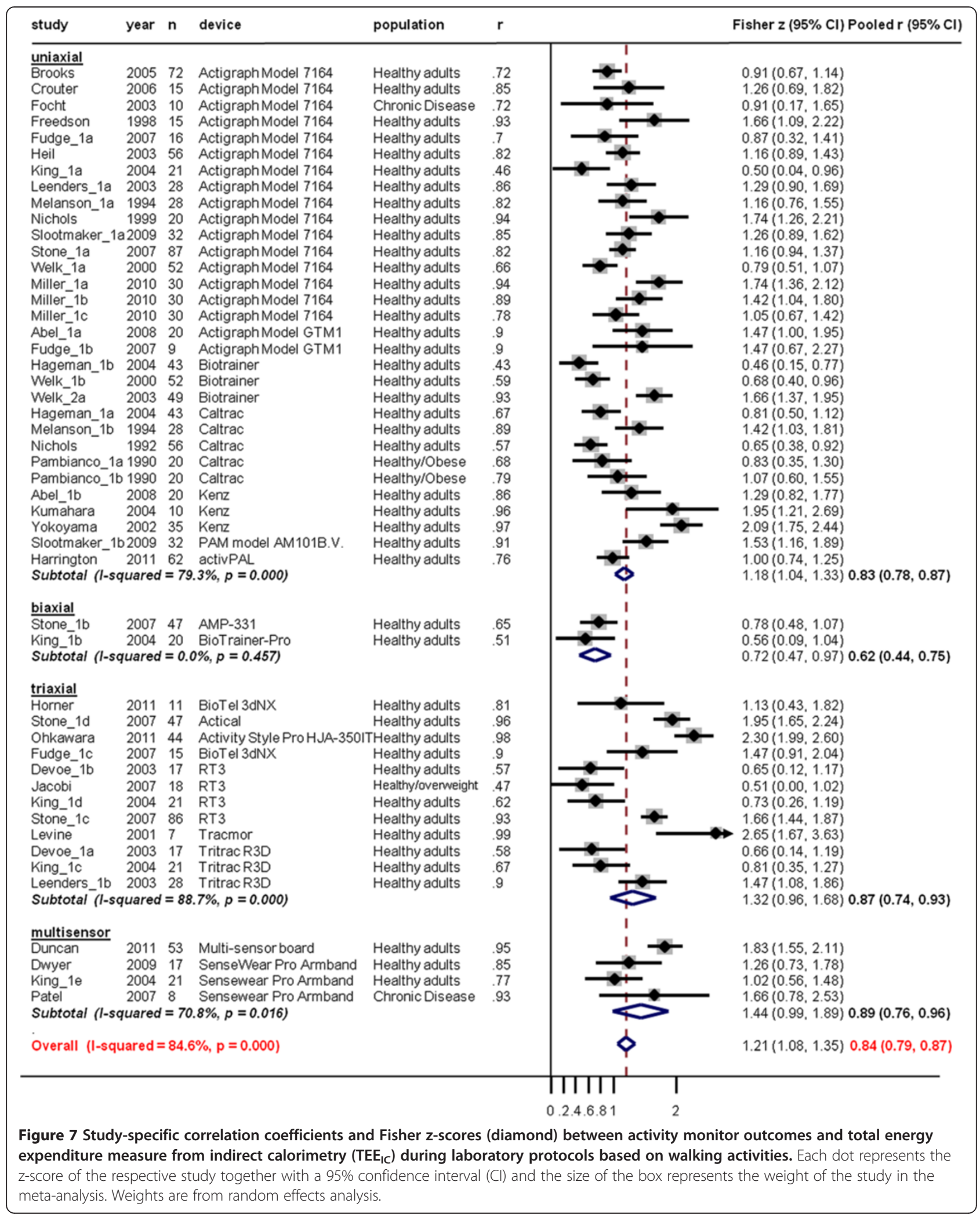




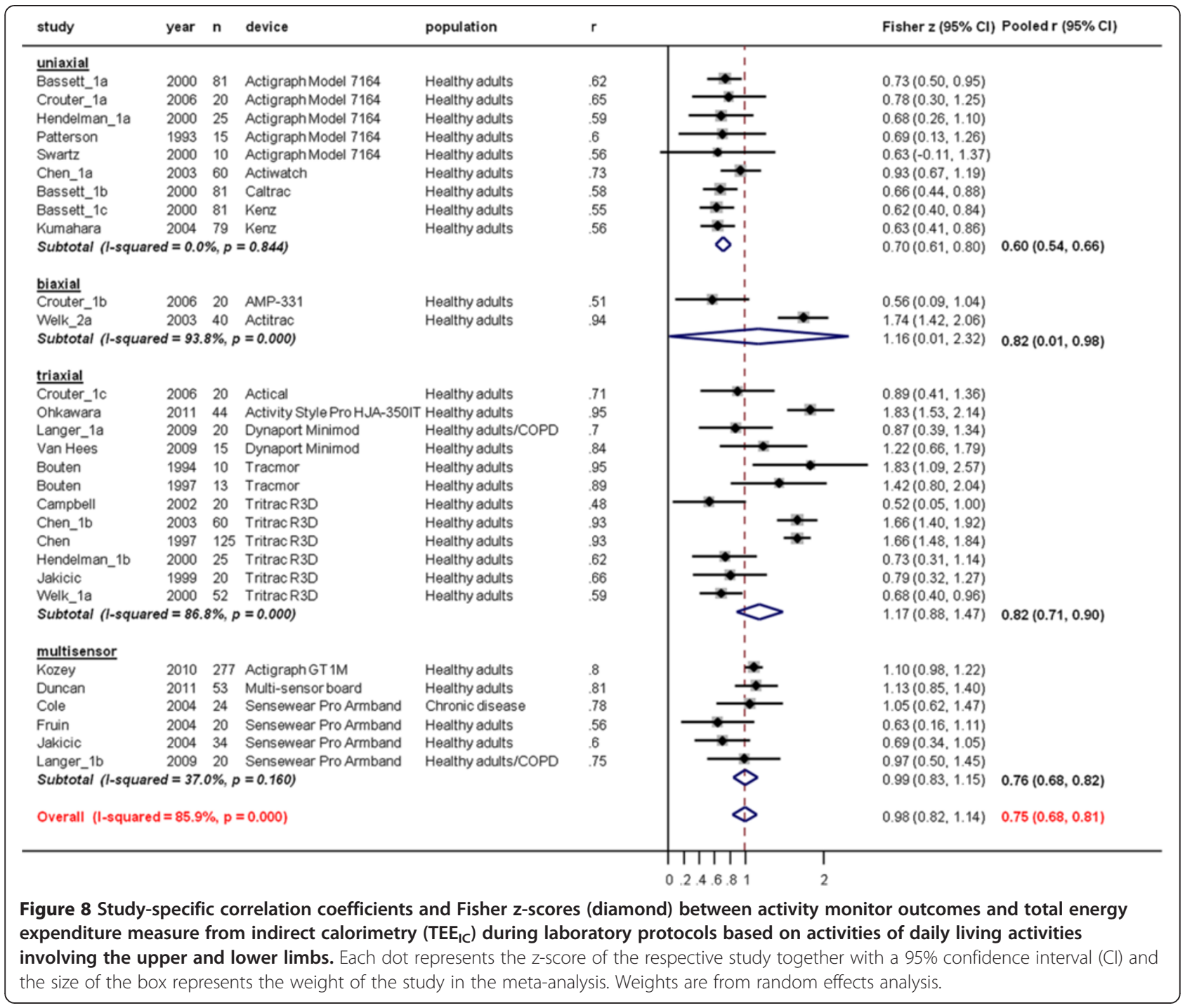

physiological parameters with accelerometry, are available to assess both body posture and body movement. An additional promising class of monitors integrate positioning systems (Global Positioning System (GPS) and Bluetooth ${ }^{\circledR}$ systems for outdoor and indoor activities respectively) with accelerometry and other sensors. However, to date, these have been used infrequently in patients with chronic disease [142,143]. Based on this systematic review, heterogeneity among studies was significantly explained by the types of devices, although no statistical significance was reached between different types of devices.

A second factor to take into consideration is the activity monitor outcome. When measuring TEE in field validation studies (doubly labelled water), high correlations with the TEE estimate of the activity monitor were found in most activity monitors. These correlations are, however, to a large extent driven by patient characteristics (i.e. body weight, age, height) [87] which is an important predictor of TEE. Consequently, the comparison of TEE estimated from activity monitors, with TEE measured with indirect calorimetry or doubly labelled water is not necessarily a proof of validation. In a field setting it has been reported that only $19 \%$ of the TEE is accounted for by physical activity in both healthy subjects [87] and in patients with coronary heart disease [144].

Another factor that needs to be considered is the study population. Most of the study populations (88\%) were healthy adults (from young healthy adults to healthy elderly). Only $12 \%$ of validation studies were performed in patients with chronic diseases (COPD, chronic heart failure, chronic organ failure, diabetes mellitus type II, obesity, peripheral arterial disease chronic low back pain 


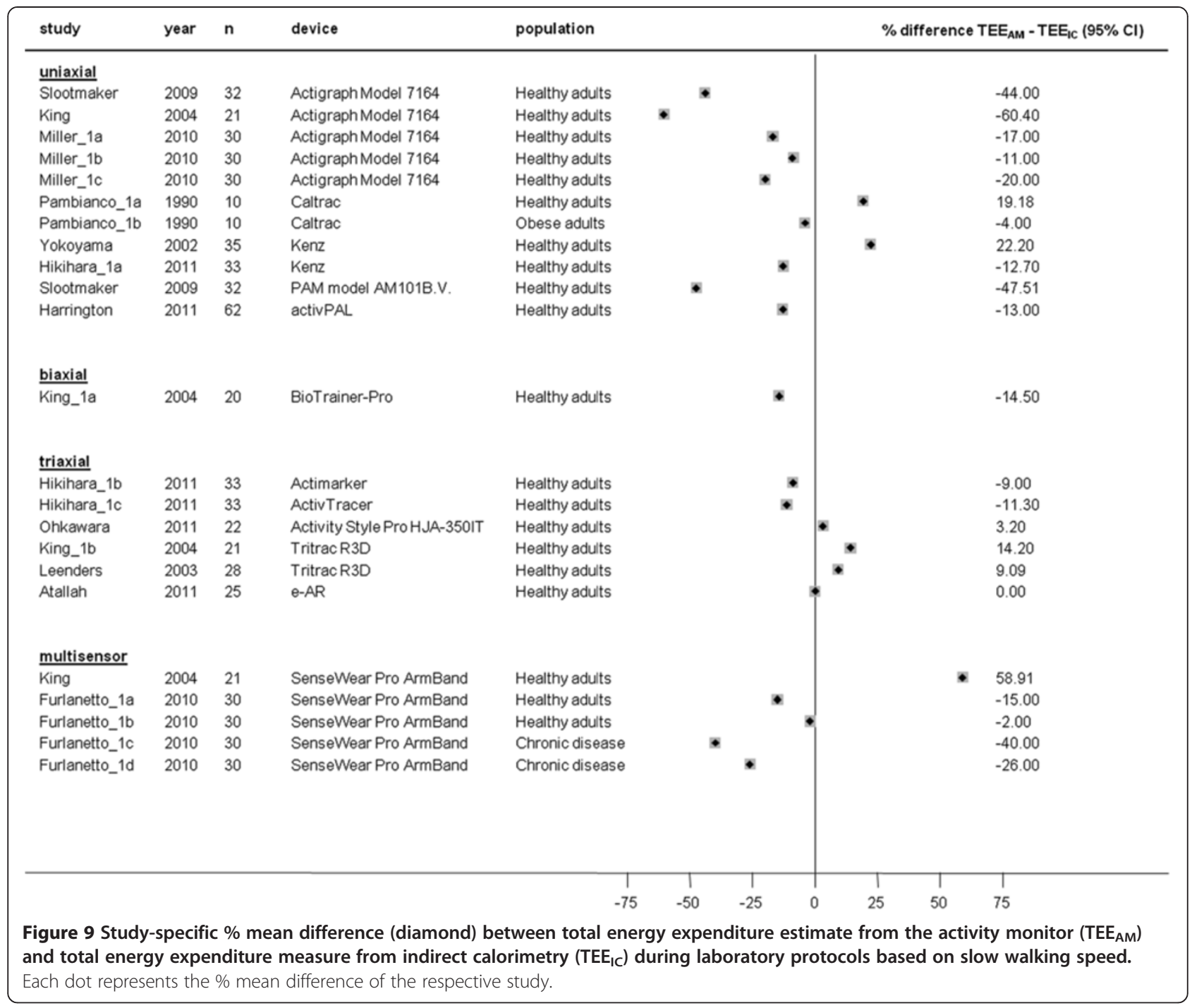

and fibromyalgia syndrome). These patients walk more slowly than healthy subjects, which is reflected, for example, by a reduced six minute walking distance $[145,146]$. This review, as well as original research [147], suggests that most monitors are less accurate at lower walking speeds. These findings are consistent with a systematic review of pedometers which found evidence of reduced accuracy during slow walking [148]. Hence, there is a need to perform validation studies specifically in chronic disease populations.

When measuring TEE in lab validation studies by assessment of oxygen consumption, higher correlations were reported for walking activities compared to other daily life activities which implies that the walking component of physical activity is better detected than other activities of daily living.

Most activity monitors use prediction equations to calculate energy expenditure from the activity signals. This is helpful to validate monitors against indirect calorimetry, but, given the inherent inaccuracy of these estimates and fundamental differences between the different prediction equations (some of which are proprietary to particular device manufacturers), perhaps greater weight should be given to direct monitor outputs (steps, activity counts, VMU, etc.) and their relation to activity energy expenditure (AEE), rather than the ability of a monitor to estimate energy expenditure precisely [48,87-89]. It is very unlikely that an activity monitor will be able to capture accurately all the factors affecting energy expenditure (i.e. movement efficiency, resting metabolism, distribution of fat-free mass and fat mass). In patients with COPD, for example, Baarends et al. showed that non-resting energy expenditure (TEE-REE) was elevated in COPD compared to healthy controls [149]. Since it is generally accepted now that these patients are less active than healthy controls $[150,151]$, it is clear that patients 


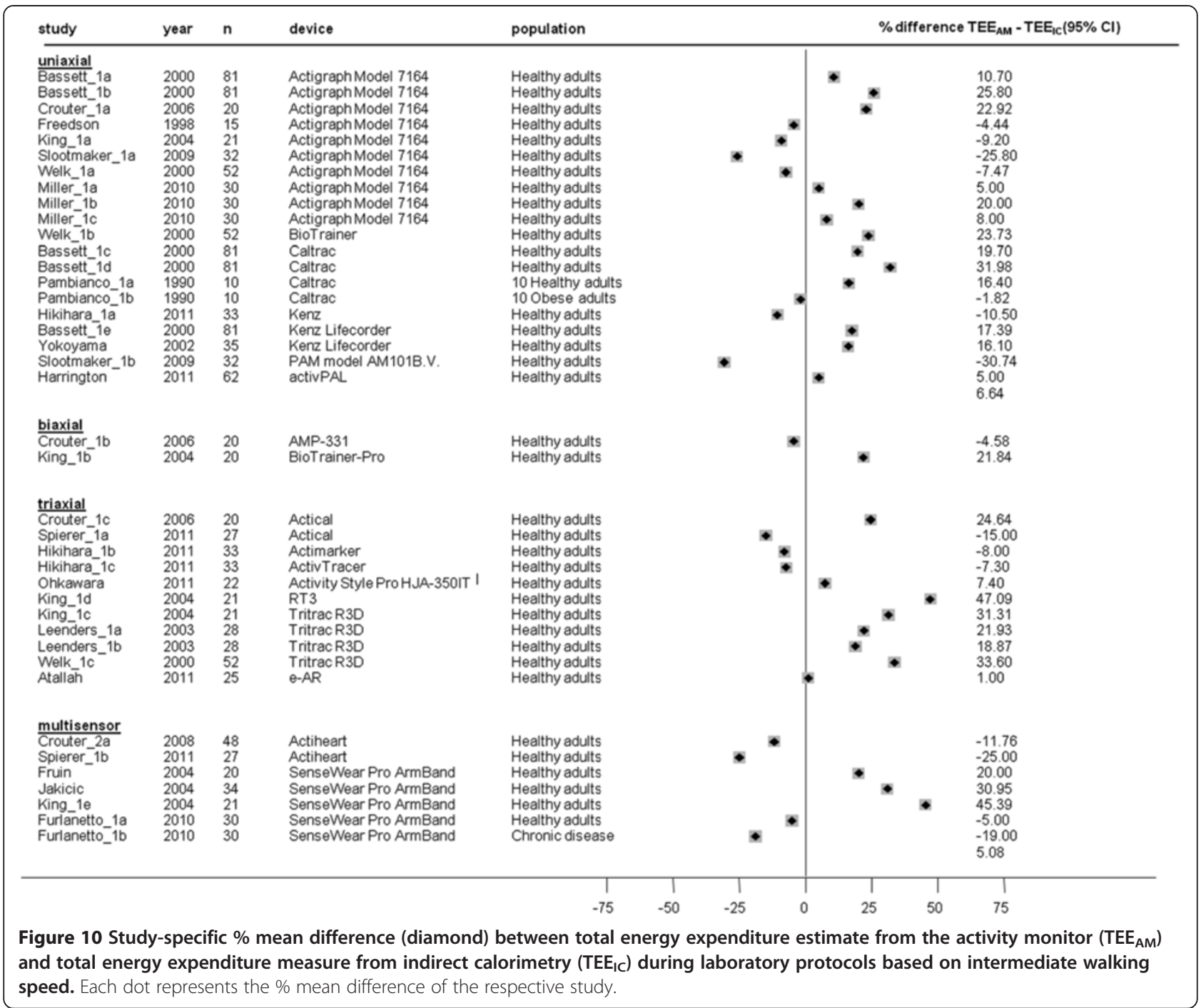

expend more energy than controls to achieve the same movements. It would be unrealistic to expect an activity monitor to pick this up. Hence, the lack of accuracy against energy expenditure does not render activity monitors invalid tools to assess physical activity in patients over time (for which precision is more important) or to capture the physical activity level of a patient (for which validity, represented by the correlation with true energy expenditure is more important than absolute accuracy). The acceptable correlations between $\mathrm{VO}_{2}$ and activity monitor outputs in triaxial and multisensor devices are therefore encouraging for the use of monitors to assess physical activity in an adult population. With specific validation studies, these findings can possibly be extrapolated to elderly and patients with chronic diseases.
The current systematic review may also help researchers to decide on appropriate activity monitor outcomes. Combination of the three most frequently available outcomes (TEE/AEE, steps and different levels of physical activity intensity), which is likely to provide a comprehensive insight in overall physical activity of a patient, is available in 3 uniaxial (Actigraph 7164/GT1M, Kenz Lifecorder EX and Polar Activity Watch 200), 1 biaxial (Biotrainer Pro), 3 triaxial (Dynaport Minimod, Actical and Actigraph GT3X) and 2 multisensor activity monitors (SenseWear Armband and multisensor board). Some general considerations can also be taken into account when selecting an activity monitor in clinical trials such as the type of monitoring (e.g. daily physical activity), size and scope of the study, usability of the monitor and cost [152]. 


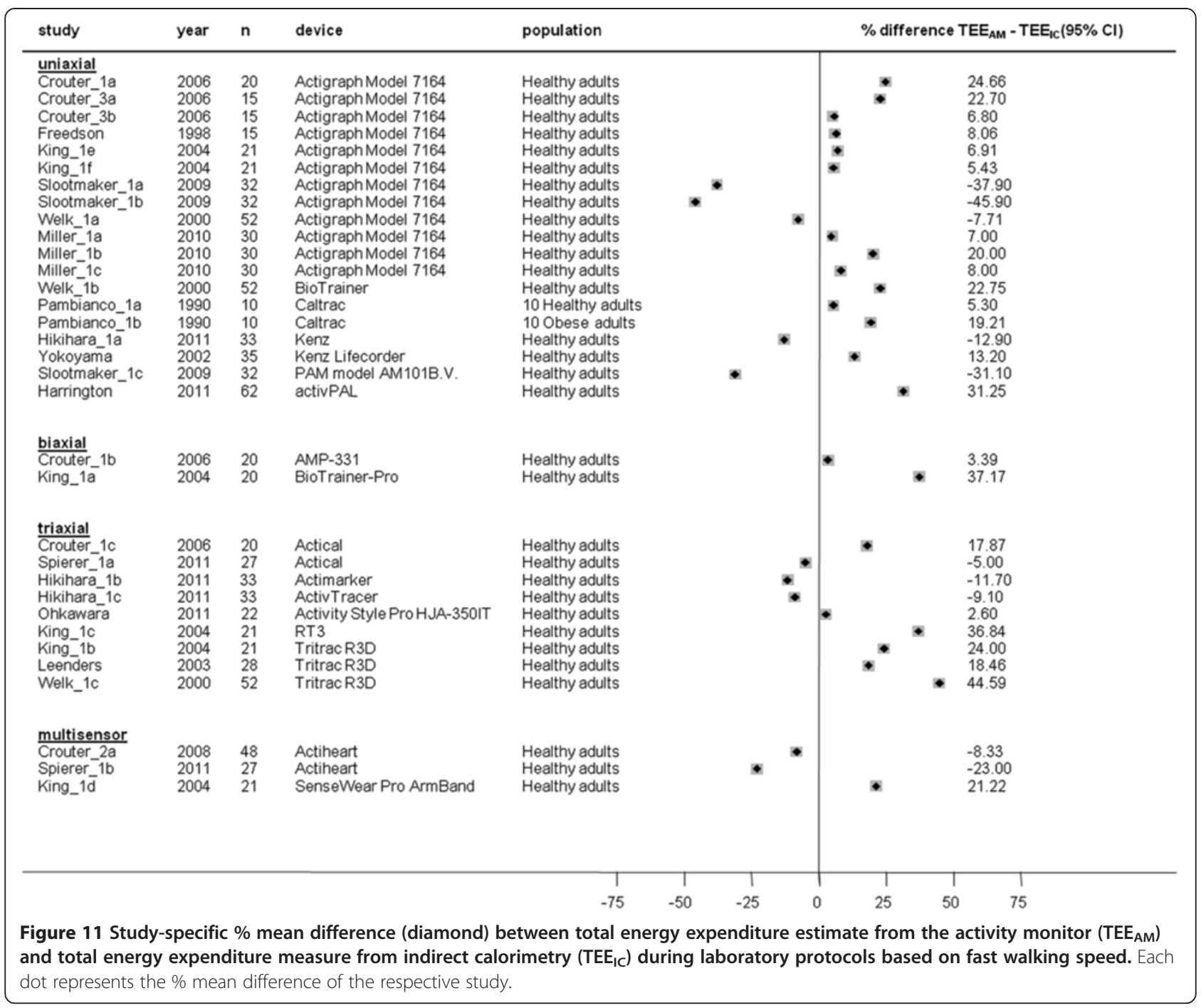

\section{Methodological issues}

A point of difficulty in collecting, analysing and interpreting the data was the wide range of statistical approaches used in the original papers. Indeed, we had to compute the standard deviation of the mean difference (between $\mathrm{EE}_{\mathrm{AM}}$ and $\mathrm{EE}_{\mathrm{IC}}$ ) because some field validation studies didn't report this.

Correlation analysis but also Bland and Altman analysis were the two main statistical approaches used in validation studies and were used for data extraction. A systematic review of the statistical methods used to validate physical activity questionnaires revealed similar findings, with the majority of the studies using correlation analysis compared to Bland and Altman analysis [153]. Correlation analyses are a common evaluation approach and allow statements on validity, whereas agreement between activity monitor and criterion method (indirect calorimetry) with Bland and Altman plots are preferred when the aim is to identify systematic bias in measures [154]. Since not all activity monitors have the possibility to estimate total and/or active energy expenditure, this type of analysis is not uniformly applicable. Multiple regression analysis with TEE/AEE as the dependent variable is a correct technique to tackle this [87]. Consistent statistical guidelines for reporting the validity of an activity monitor would be helpful.

\section{Conclusion}

Validation studies of activity monitors are highly heterogeneous, and this is partly explained by the type of activity monitor and the activity monitor outcome. Since activity monitors are less accurate at slow walking speeds and information about validated activity monitors in chronic disease populations is lacking, proper validation studies in these populations are needed prior to their inclusion in clinical trials. 


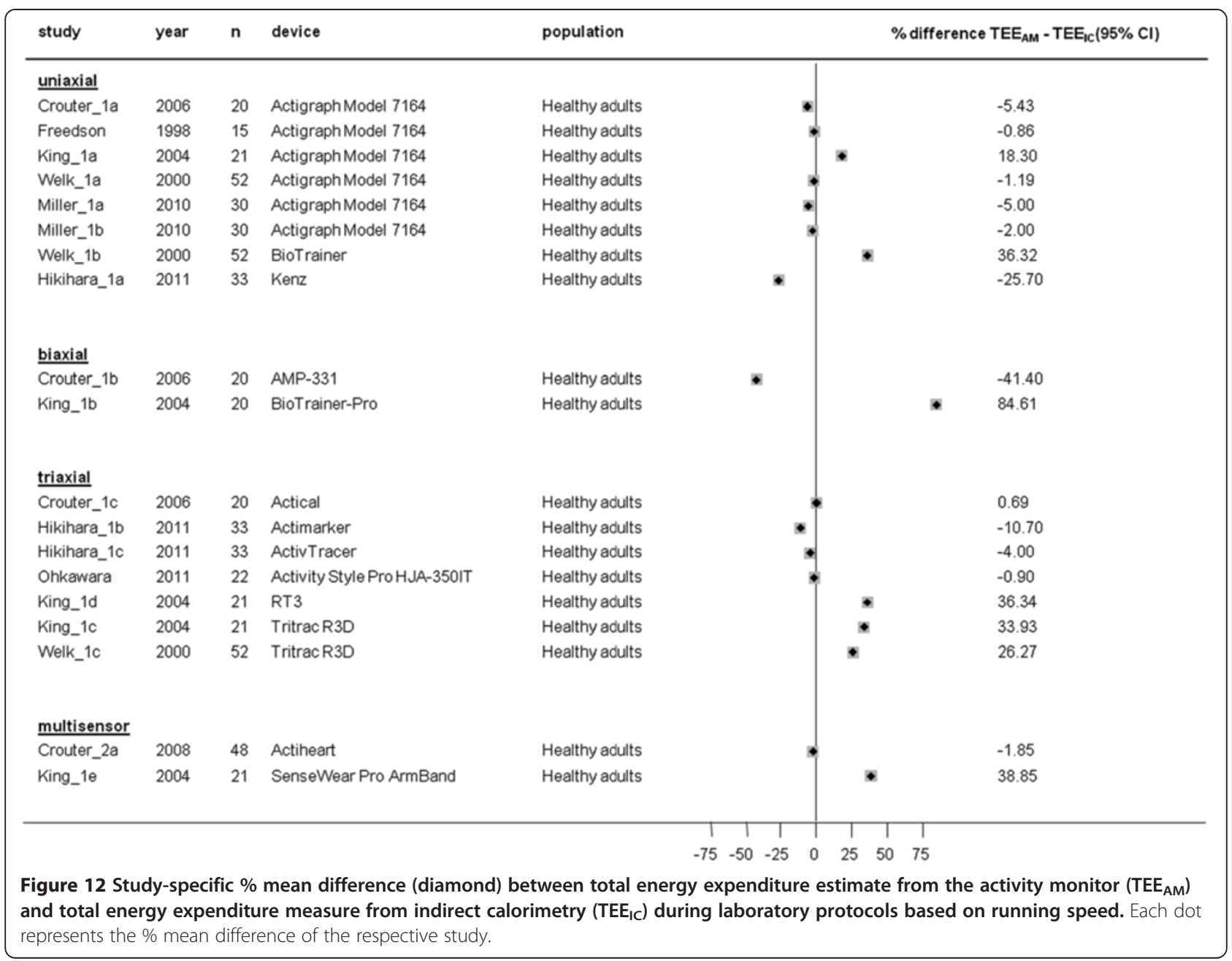

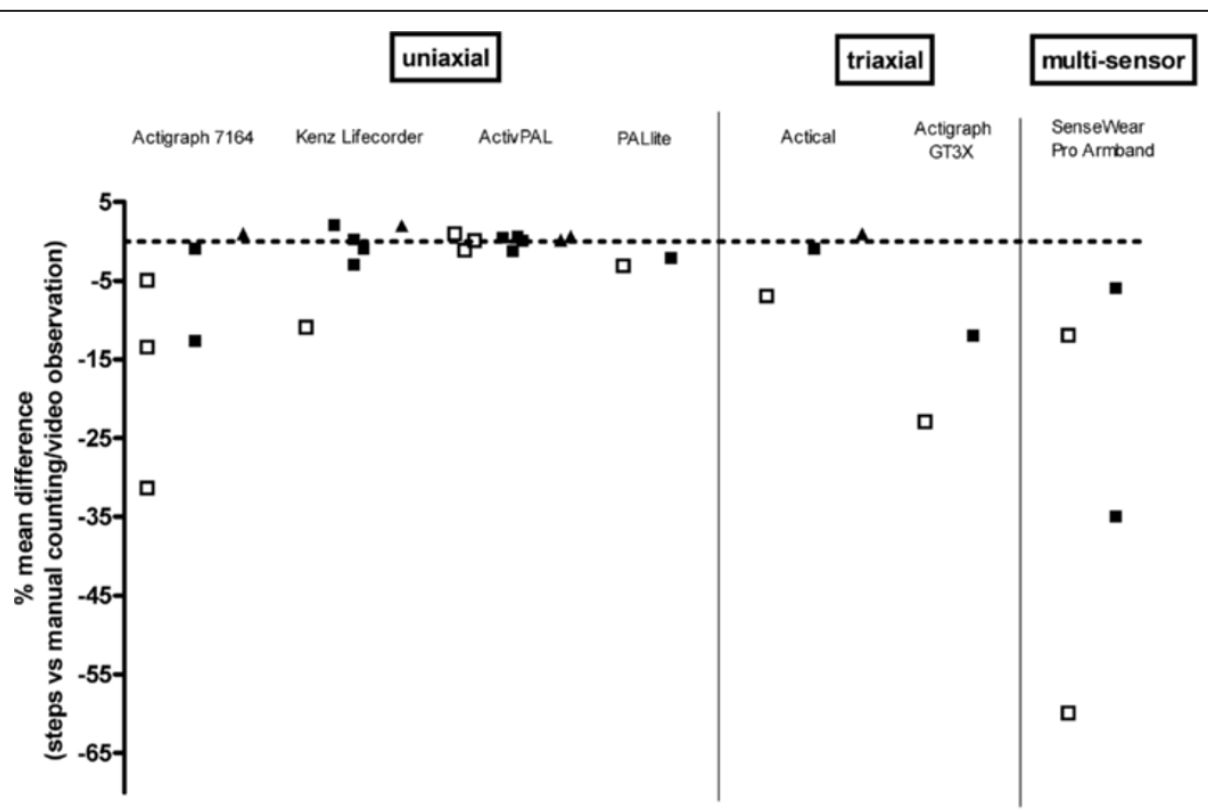

Figure 13 Accuracy of steps at different walking speeds. The dots are reflecting walking speed: slow walking $(<3.2 \mathrm{~km} / \mathrm{hr}(\square))$, intermediate walking (3.2-6.4 km/hr (- $))$ and fast walking $(6.5-8 \mathrm{~km} / \mathrm{hr}(\mathbf{\Delta}))$. 


\section{Additional files}

\section{Additional file 1: Details of the search strategy terms in the} different databases.

\section{Abbreviations}

AEE: Active energy expenditure; $\mathrm{AEE}_{\mathrm{AM}}$ : Estimation of active energy expenditure by an activity monitor; $A E E_{D L W}$ : Measurement of active energy expenditure by doubly labelled water; $A E E_{1}$ : Measurement of active energy expenditure by indirect calorimetry; AM: Activity monitor; COPD: Chronic obstructive pulmonary disease; DLW: Doubly labelled water; GPS: Global positioning system; IC: Indirect calorimetry; TEE: Total energy expenditure; $\mathrm{TEE}_{\mathrm{AM}}$ : Estimation of total energy expenditure by an activity monitor; TEE $E_{D L W}$ : Measurement of total energy expenditure by doubly labelled water; $T E E_{I C}$ : Measurement of total energy expenditure by indirect calorimetry.

\section{Competing interests}

The authors declare not having financial or non-financial competing interests.

\section{Authors' contributions}

All authors contributed to the different processes in the systematic review (title and abstract screening, full text assessment and data extraction). HVR worked out an appropriate search term strategy in different databases. HVR and SG have been involved in analysing the data and drafting the manuscript which was revised by all the other authors. MP performed the statistical analysis. All authors read and approved the final manuscript.

\section{Authors' information}

This systematic review is part of the PROactive project (www.proactivecopd. com) which aims to develop a Patient Reported Outcome (PRO) tool capturing physical activity in COPD in close harmony with a valid activity monitor.

\section{Acknowledgements}

The authors would like to thank Jens De Groot (librarian at Biomedical Library, Katholieke Universiteit Leuven, Belgium) for his assistance in the search strategy of the different databases. This work (as part of the PROactive project) is funded by the Innovative Medicines Initiative Joint Undertaking (IMI-JU) and EFPIA \# 115011

The authors would like to acknowledge the members of the PROactive consortium for the outstanding contribution to this work.

PROactive consortium: Chiesi Farmaceutici S.A.: Caterina Brindicci, Tim Higenbottam; Katholieke Universiteit Leuven: Thierry Troosters, Fabienne Dobbels, Marc Decramer; Glaxo Smith Kline: Margaret X. Tabberer; University of Edinburgh, Old College South Bridge: Roberto A Rabinovich, William McNee; Thorax Research Foundation, Athens: Ioannis Vogiatzis; Royal Brompton and Harefield NHS Foundation Trust: Michael Polkey, Nick Hopkinson; Municipal Institute of Medical Research, Barcelona: Judith GarciaAymerich; Universität Zürich, Zürich: Milo Puhan, Anja Frei; University Medical Center, Groningen: Thys van der Molen, Corina De Jong; Netherlands Asthma Foundation, Leusden: Pim de Boer; British Lung Foundation, UK: Ian Jarrod; Choice Healthcare Solution, UK: Paul McBride; European Respiratory Society, Lausanne: Nadia Kamel; Pfizer: Katja Rudell, Frederick J. Wilson; Almirall: Nathalie Ivanoff; Novartis: Karoly Kulich, Alistair Glendenning; AstraZeneca AB: Niklas X. Karlsson, Solange Corriol-Rohou; UCB: Enkeleida Nikai; Boehringer Ingelheim: Damijen Erzen.

C.B. is a doctoral fellow of the Research Foundation Flanders. D.L. is a post doctoral fellow of the Research Foundation Flanders.

N.S.H. and Y.R. are supported by the NIHR Respiratory Biomedical Research Unit at Royal Brompton and Harefield NHS Foundation Trust and Imperial College, London, United Kingdom.

\section{Author details}

${ }^{1}$ Faculty of Kinesiology and Rehabilitation Sciences, Department of Rehabilitation Sciences, Katholieke Universiteit Leuven, Leuven, Belgium and Respiratory Division, UZ Gasthuisberg, Leuven, Belgium. '²LEGl Colt Laboratory, Centre for Inflammation Research, University of Edinburgh, Edinburgh, Scotland, United Kingdom. ${ }^{3} \mathrm{NIHR}$ Respiratory Biomedical Research Unit at Royal Brompton and Harefield NHS Foundation Trust and Imperial College, London, United Kingdom. ${ }^{4}$ Department of Physical
Education and Sports Sciences, Thorax Foundation, Research Centre of Intensive \& Emergency Thoracic Medicine, Athens, Greece and National \& Kapodistrian University of Athens, Athens, Greece. ${ }^{5}$ Centre for Research in Environmental Epidemiology, Barcelona, Spain. ${ }^{6}$ Global Health Economics and Outcomes Research, Novartis Horsham Research Centre, Horsham, United Kingdom. ${ }^{7}$ Precision Medicine, Pfizer Worldwide Research and Development, Sandwich, Kent, United Kingdom. ${ }^{8}$ Horten Centre for Patientoriented Research, University Hospital of Zürich, Zürich, Switzerland. ${ }^{9}$ Department of Epidemiology, Johns Hopkins Bloomberg School of Public Health, Baltimore, MD, USA. ${ }^{10}$ PROactive consortium, Europe, Europe.

${ }^{11}$ Respiratory Rehabilitation and Respiratory Division, UZ Gasthuisberg, Herestraat 49 bus 706, Onderwijs \& Navorsing I, Labo Pneumologie, B-3000, Leuven, Belgium.

Received: 17 November 2011 Accepted: 13 June 2012 Published: 9 July 2012

\section{References}

1. Warburton DE, Nicol CW, Bredin SS: Health benefits of physical activity: the evidence. CMAJ 2006, 174:801-809.

2. Blair SN, Cheng Y, Holder JS: Is physical activity or physical fitness more important in defining health benefits? Med Sci Sports Exerc 2001, 33:S379-S399. discussion S419-320.

3. Garcia-Aymerich J, Lange P, Benet M, Schnohr P, Anto JM: Regular physical activity reduces hospital admission and mortality in chronic obstructive pulmonary disease: a population based cohort study. Thorax 2006, 61:772-778

4. Caspersen CJ, Powell KE, Christenson GM: Physical activity, exercise, and physical fitness: definitions and distinctions for health-related research. Public Health Rep 1985, 100:126-131.

5. Steele BG, Belza B, Cain K, Warms C, Coppersmith J, Howard J: Bodies in motion: monitoring daily activity and exercise with motion sensors in people with chronic pulmonary disease. J Rehabil Res Dev 2003, 40:45-58.

6. Garcia-Aymerich J, Serra I, Gomez FP, Farrero E, Balcells E, Rodriguez DA, de Batlle J, Gimeno E, Donaire-Gonzalez D, Orozco-Levi M, et al: Physical activity and clinical and functional status in COPD. Chest 2009, 136:62-70.

7. Bassett DR Jr, Ainsworth BE, Swartz AM, Strath SJ, O'Brien WL, King GA: Validity of four motion sensors in measuring moderate intensity physical activity. Med Sci Sports Exerc 2000, 32:S471-S480.

8. Le Masurier GC, Tudor-Locke C: Comparison of pedometer and accelerometer accuracy under controlled conditions. Med Sci Sports Exerc 2003, 35:867-871.

9. Plasqui G, Westerterp KR: Physical activity assessment with accelerometers: an evaluation against doubly labeled water. Obesity (Silver Spring) 2007, 15:2371-2379.

10. Cyarto EV, Myers AM, Tudor-Locke C: Pedometer accuracy in nursing home and community-dwelling older adults. Med Sci Sports Exerc 2004 36:205-209.

11. Giacomozzi C, Caselli A, Macellari V, Giurato L, Lardieri L, Uccioli L: Walking strategy in diabetic patients with peripheral neuropathy. Diabetes Care 2002, 25:1451-1457.

12. Guazzi M, Dickstein K, Vicenzi M, Arena R: Six-minute walk test and cardiopulmonary exercise testing in patients with chronic heart failure: a comparative analysis on clinical and prognostic insights. Circ Heart Fail 2009, 2:549-555.

13. Corey DM, Dunlap WP: Averaging Correlations: expected Values and Bias in Combined Pearson rs and Fisher's z Transformations. J Gen Psychol $1998,125: 245-261$.

14. Leenders NY, Sherman WM, Nagaraja HN: Energy expenditure estimated by accelerometry and doubly labeled water: do they agree? Med Sci Sports Exerc 2006, 38:2165-2172.

15. Adams SA, Matthews CE, Ebbeling CB, Moore CG, Cunningham JE, Fulton J, Hebert JR: The effect of social desirability and social approval on selfreports of physical activity. Am J Epidemiol 2005, 161:389-398.

16. Leenders NY, Sherman WM, Nagaraja HN, Kien CL: Evaluation of methods to assess physical activity in free-living conditions. Med Sci Sports Exerc 2001, 33:1233-1240.

17. Dalton AF, Ni Scanaill C, Carew S, Lyons D, OL G: A clinical evaluation of a remote mobility monitoring system based on SMS messaging. Conf Proc IEEE Eng Med Biol Soc 2007, 2007:2327-2330. 
18. Kochersberger G, McConnell E, Kuchibhatla MN, Pieper C: The reliability, validity, and stability of a measure of physical activity in the elderly. Arch Phys Med Rehabil 1996, 77:793-795.

19. Masse LC, Fulton JE, Watson KL, Heesch KC, Kohl HW 3rd, Blair SN, Tortolero SR: Detecting bouts of physical activity in a field setting. Res Q Exerc Sport 1999, 70:212-219.

20. McClain JJ, Craig CL, Sisson SB, Tudor-Locke C: Comparison of Lifecorder EX and ActiGraph accelerometers under free-living conditions. Appl Physiol Nutr Metab 2007, 32:753-761.

21. Paul DR, Kramer M, Moshfegh AJ, Baer DJ, Rumpler W: Comparison of two different physical activity monitors. BMC Med Res Methodol 2007, 7:26.

22. Lof M, Hannestad U, Forsum E: Comparison of commonly used procedures, including the doubly-labelled water technique, in the estimation of total energy expenditure of women with special reference to the significance of body fatness. Br J Nutr 2003, 90:961-968

23. Masse LC, Fulton JE, Watson KL, Mahar MT, Meyers MC, Wong WW: Influence of body composition on physical activity validation studies using doubly labeled water. J Appl Physio/ 2004, 96:1357-1364.

24. Patrik Johansson H, Rossander-Hulthen L, Slinde F, Ekblom B: Accelerometry combined with heart rate telemetry in the assessment of total energy expenditure. Br J Nutr 2006, 95:631-639.

25. Brooks AG, Gunn SM, Withers RT, Gore CJ, Plummer JL: Predicting walking METs and energy expenditure from speed or accelerometry. Med Sci Sports Exerc 2005, 37:1216-1223.

26. Crouter SE, Churilla JR, Bassett DR Jr: Estimating energy expenditure using accelerometers. Eur J Appl Physiol 2006, 98:601-612.

27. Focht BC: Initial Validation of the CSA Activity Monitor During Rehabilitative Exercise Among Older Adults With Chronic Disease. Journal of Aging and Physical Activity 2003, 11:293-304.

28. Freedson PS, Melanson E, Sirard J: Calibration of the Computer Science and Applications, Inc. accelerometer. Med Sci Sports Exerc 1998, 30:777-781.

29. Fudge BW, Wilson J, Easton C, Irwin L, Clark J, Haddow O, Kayser B, Pitsiladis YP: Estimation of oxygen uptake during fast running using accelerometry and heart rate. Med Sci Sports Exerc 2007, 39:192-198.

30. Heil DP: Body size as a determinant of activity moniyor output during overground walking. JEP online 2003, 6:1-11.

31. Hendelman D, Miller K, Baggett C, Debold E, Freedson P: Validity of accelerometry for the assessment of moderate intensity physical activity in the field. Med Sci Sports Exerc 2000, 32:S442-S449.

32. King GA, Torres N, Potter C, Brooks TJ, Coleman KJ: Comparison of activity monitors to estimate energy cost of treadmill exercise. Med Sci Sports Exerc 2004, 36:1244-1251.

33. Leenders NY, Nelson TE, Sherman WM: Ability of different physical activity monitors to detect movement during treadmill walking. Int J Sports Med 2003, 24:43-50.

34. Melanson EL Jr, Freedson PS: Validity of the Computer Science and Applications, Inc. (CSA) activity monitor. Med Sci Sports Exerc 1995 27:934-940.

35. Nichols JF, Patterson P, Early T: A validation of a physical activity monitor for young and older adults. Can J Sport Sci 1992, 17:299-303.

36. Patterson SM, Krantz DS, Montgomery LC, Deuster PA, Hedges SM, Nebel LE: Automated physical activity monitoring: validation and comparison with physiological and self-report measures. Psychophysiology 1993, 30:296-305.

37. Slootmaker SM, Chin APMJ, Schuit AJ, van Mechelen W, Koppes LL: Concurrent validity of the PAM accelerometer relative to the MTI Actigraph using oxygen consumption as a reference. Scand J Med Sci Sports 2009, 19:36-43.

38. Stone MR, Esliger DW, Tremblay MS: Comparative validity assessment of five activity monitors: does being a child matter? Pediatr Exerc Sci 2007, 19:291-309.

39. Strath SJ, Bassett DR Jr, Thompson DL, Swartz AM: Validity of the simultaneous heart rate-motion sensor technique for measuring energy expenditure. Med Sci Sports Exerc 2002, 34:888-894.

40. Swartz AM, Strath SJ, Bassett DR Jr, O'Brien WL, King GA, Ainsworth BE: Estimation of energy expenditure using CSA accelerometers at hip and wrist sites. Med Sci Sports Exerc 2000, 32:S450-S456.
41. Welk GJ, Blair SN, Wood K, Jones S, Thompson RW: A comparative evaluation of three accelerometry-based physical activity monitors. Med Sci Sports Exerc 2000, 32:S489-S497.

42. Crouter SE, Clowers KG, Bassett DR Jr: A novel method for using accelerometer data to predict energy expenditure. J Appl Physiol 2006, 100:1324-1331.

43. Nichols JF, Morgan CG, Chabot LE, Sallis JF, Calfas KJ: Assessment of physical activity with the Computer Science and Applications, Inc., accelerometer: laboratory versus field validation. Res Q Exerc Sport 2000, 71:36-43.

44. Esliger DW, Probert A, Gorber SC, Bryan S, Laviolette M, Tremblay MS: Validity of the Actical accelerometer step-count function. Med Sci Sports Exerc 2007, 39:1200-1204.

45. Storti KL, Pettee KK, Brach JS, Talkowski JB, Richardson CR, Kriska AM: Gait speed and step-count monitor accuracy in community-dwelling older adults. Med Sci Sports Exerc 2008, 40:59-64.

46. Berntsen S, Hageberg R, Aandstad A, Mowinckel P, Anderssen SA, Carlsen $\mathrm{KH}$, Andersen LB: Validity of physical activity monitors in adults participating in free-living activities. Br J Sports Med 2010, 44:657-664.

47. Miller NE, Strath SJ, Swartz AM, Cashin SE: Estimating absolute and relative physical activity intensity across age via accelerometry in adults. J Aging Phys Act 2010, 18:158-170.

48. Assah FK, Ekelund U, Brage S, Corder K, Wright A, Mbanya JC, Wareham NJ: Predicting physical activity energy expenditure using accelerometry in adults from sub-Sahara Africa. Obesity (Silver Spring) 2009, 17:1588-1595.

49. Rothney MP, Brychta RJ, Meade NN, Chen KY, Buchowski MS: Validation of the ActiGraph two-regression model for predicting energy expenditure. Med Sci Sports Exerc 2010, 42:1785-1792.

50. Colbert LH, Matthews CE, Havighurst TC, Kim K, Schoeller DA: Comparative validity of physical activity measures in older adults. Med Sci Sports Exerc 2011, 43:867-876.

51. Abel MG, Hannon JC, Sell K, Lillie T, Conlin G, Anderson D: Validation of the Kenz Lifecorder EX and ActiGraph GT1M accelerometers for walking and running in adults. App/ Physiol Nutr Metab 2008, 33:1155-1164.

52. Edwards AG, Hill JO, Byrnes WC, Browning RC: Accuracy of optimized branched algorithms to assess activity-specific physical activity energy expenditure. Med Sci Sports Exerc 2010, 42:672-682.

53. Kozey SL, Lyden K, Howe CA, Staudenmayer JW, Freedson PS: Accelerometer output and MET values of common physical activities. Med Sci Sports Exerc 2010, 42:1776-1784.

54. Lyden K, Kozey SL, Staudenmeyer JW, Freedson PS: A comprehensive evaluation of commonly used accelerometer energy expenditure and MET prediction equations. Eur J Appl Physiol 2011, 111:187-201.

55. Esliger DW, Rowlands AV, Hurst TL, Catt M, Murray P, Eston RG: Validation of the GENEA Accelerometer. Med Sci Sports Exerc 2010, 43:1085-1093.

56. Kuffel EE, Crouter SE, Haas JD, Frongillo EA, Bassett DR Jr: Validity of estimating minute-by-minute energy expenditure of continuous walking bouts by accelerometry. Int J Behav Nutr Phys Act 2011, 8:92.

57. Harrington DM, Welk GJ, Donnelly AE: Validation of MET estimates and step measurement using the ActivPAL physical activity logger. J Sports Sci 2011, 29:627-633

58. Fogelholm M, Hiilloskorpi H, Laukkanen R, Oja P, Van Marken Lichtenbelt W, Westerterp K: Assessment of energy expenditure in overweight women. Med Sci Sports Exerc 1998, 30:1191-1197.

59. Fuller Z, Horgan G, O'Reilly LM, Ritz P, Milne E, Stubbs RJ: Comparing different measures of energy expenditure in human subjects resident in a metabolic facility. Eur J Clin Nutr 2008, 62:560-569.

60. Gardner AW, Womack CJ, Sieminski DJ, Montgomery PS, Killewich LA, Fonong T: Relationship between free-living daily physical activity and ambulatory measures in older claudicants. Angiology 1998, 49:327-337

61. Starling RD, Matthews DE, Ades PA, Poehlman ET: Assessment of physical activity in older individuals: a doubly labeled water study. J Appl Physiol 1999, 86:2090-2096.

62. Choquette S, Chuin A, Lalancette DA, Brochu M, Dionne IJ: Predicting energy expenditure in elders with the metabolic cost of activities. Med Sci Sports Exerc 2009, 41:1915-1920. 
63. Fehling PC, Smith DL, Warner SE, Dalsky GP: Comparison of accelerometers with oxygen consumption in older adults during exercise. Med Sci Sports Exerc 1999, 31:171-175

64. Hageman PA: Comparison of two Physical Activity Monitors During a 1-Mile Walking field test. JEP online 2004, 7:102-110.

65. Pambianco G, Wing RR, Robertson R: Accuracy and reliability of the Caltrac accelerometer for estimating energy expenditure. Med Sci Sports Exerc 1990, 22:858-862

66. Rafamantanantsoa HH, Ebine N, Yoshioka M, Higuchi H, Yoshitake Y, Tanaka H, Saitoh S, Jones PJ: Validation of three alternative methods to measure total energy expenditure against the doubly labeled water method for older Japanese men. J Nutr Sci Vitaminol (Tokyo) 2002, 48:517-523.

67. Yamada Y, Yokoyama K, Noriyasu R, Osaki T, Adachi T, Itoi A, Naito Y, Morimoto T, Kimura M, Oda S: Light-intensity activities are important for estimating physical activity energy expenditure using uniaxial and triaxial accelerometers. Eur J Appl Physiol 2009, 105:141-152.

68. Kumahara H, Schutz Y, Ayabe M, Yoshioka M, Yoshitake Y, Shindo M, Ishii K Tanaka $\mathrm{H}$ : The use of uniaxial accelerometry for the assessment of physical-activity-related energy expenditure: a validation study against whole-body indirect calorimetry. Br J Nutr 2004, 91:235-243.

69. Schneider PL, Crouter SE, Lukajic O, Bassett DR Jr: Accuracy and reliability of 10 pedometers for measuring steps over a 400-m walk. Med Sci Sports Exerc 2003, 35:1779-1784

70. Ohkawara K, Ishikawa-Takata K, Park JH, Tabata I, Tanaka S: How much locomotive activity is needed for an active physical activity level: analysis of total step counts. BMC Res Notes 2011, 4:512.

71. Yokoyama Y, Kawamura T, Tamakoshi A, Noda A, Hirai M, Saito H, Ohno Y: Comparison of accelerometry and oxymetry for measuring daily physical activity. Circ J 2002, 66:751-754.

72. Grant PM, Dall PM, Mitchell SL, Granat MH: Activity-monitor accuracy in measuring step number and cadence in community-dwelling older adults. J Aging Phys Act 2008, 16:201-214.

73. Ryan CG, Grant PM, Tigbe WW, Granat MH: The validity and reliability of a novel activity monitor as a measure of walking. Br J Sports Med 2006, 40:779-784.

74. Maddocks M, Petrou A, Skipper L, Wilcock A: Validity of three accelerometers during treadmill walking and motor vehicle travel. $\mathrm{Br} J$ Sports Med 2010, 44:606-608.

75. Chen KY, Acra SA, Majchrzak K, Donahue CL, Baker L, Clemens L, Sun M, Buchowski MS: Predicting energy expenditure of physical activity using hip- and wrist-worn accelerometers. Diabetes Technol Ther 2003, 5:1023-1033.

76. Welk GJ, Almeida J, Morss G: Laboratory calibration and validation of the Biotrainer and Actitrac activity monitors. Med Sci Sports Exerc 2003, 35:1057-1064

77. Kane NA, Simmons MC, John D, Thompson DL, Bassett DR: Validity of the Nike+ device during walking and running. Int J Sports Med 2010, 31:101-105.

78. Brugniaux JV, Niva A, Pulkkinen I, Laukkanen RM, Richalet JP, Pichon AP: Polar Activity Watch 200: a new device to accurately assess energy expenditure. Br J Sports Med 2010, 44:245-249.

79. Connolly CP, Coe DP, Kendrick JM, Bassett DR Jr, Thompson DL: Accuracy of physical activity monitors in pregnant women. Med Sci Sports Exerc 2010, 43:1100-1105.

80. Jacobi D, Perrin AE, Grosman N, Dore MF, Normand S, Oppert JM, Simon C Physical activity-related energy expenditure with the RT3 and TriTrac accelerometers in overweight adults. Obesity (Silver Spring) 2007 15:950-956.

81. Maddison R, Jiang Y, Hoorn SV, Mhurchu CN, Lawes CM, Rodgers A, Rush E: Estimating energy expenditure with the RT3 triaxial accelerometer. Res $Q$ Exerc Sport 2009, 80:249-256.

82. DeVoe D, Gotshall R, McArthur T: Comparison of the RT3 Research Tracker and Tritrac R3D accelerometers. Percept Mot Skills 2003, 97:510-518.

83. Howe CA, Staudenmayer JW, Freedson PS: Accelerometer prediction of energy expenditure: vector magnitude versus vertical axis. Med Sci Sports Exerc 2009, 41:2199-2206.

84. Campbell KL, Crocker PR, McKenzie DC: Field evaluation of energy expenditure in women using Tritrac accelerometers. Med Sci Sports Exerc 2002, 34:1667-1674.
85. Chen KY, Sun M: Improving energy expenditure estimation by using a triaxial accelerometer. J Appl Physiol 1997, 83:2112-2122.

86. Jakicic JM, Winters C, Lagally K, Ho J, Robertson RJ, Wing RR: The accuracy of the TriTrac-R3D accelerometer to estimate energy expenditure. Med Sci Sports Exerc 1999, 31:747-754.

87. Plasqui $G$, Joosen AM, Kester AD, Goris AH, Westerterp KR: Measuring freeliving energy expenditure and physical activity with triaxial accelerometry. Obes Res 2005, 13:1363-1369.

88. Bouten CV, Verboeket-van de Venne WP, Westerterp KR, Verduin M, Janssen JD: Daily physical activity assessment: comparison between movement registration and doubly labeled water. J Appl Physiol 1996, 81:1019-1026.

89. Meijer EP, Goris AH, Wouters L, Westerterp KR: Physical inactivity as a determinant of the physical activity level in the elderly. Int J Obes Relat Metab Disord 2001, 25:935-939.

90. Bonomi AG, Plasqui $G$, Goris AH, Westerterp KR: Estimation of free-living energy expenditure using a novel activity monitor designed to minimize obtrusiveness. Obesity (Silver Spring) 2010, 18:1845-1851.

91. Goris AH, Meijer EP, Kester A, Westerterp KR: Use of a triaxial accelerometer to validate reported food intakes. Am J Clin Nutr 2001, 73:549-553.

92. Meijer GA, Westerterp KR, van Hulsel AM, ten Hoor F: Physical activity and energy expenditure in lean and obese adult human subjects. Eur J Appl Physiol Occup Physiol 1992, 65:525-528.

93. Pietilainen KH, Kaprio J, Borg P, Plasqui G, Yki-Jarvinen H, Kujala UM, Rose RJ, Westerterp KR, Rissanen A: Physical inactivity and obesity: a vicious circle. Obesity (Silver Spring) 2008, 16:409-414.

94. Verbunt JA, Westerterp KR, van der Heijden GJ, Seelen HA, Vlaeyen JW, Knottnerus JA: Physical activity in daily life in patients with chronic low back pain. Arch Phys Med Rehabil 2001, 82:726-730.

95. Bouten CV, Koekkoek KT, Verduin M, Kodde R, Janssen JD: A triaxial accelerometer and portable data processing unit for the assessment of daily physical activity. IEEE Trans Biomed Eng 1997 44:136-147.

96. Bouten CV, Westerterp KR, Verduin M, Janssen JD: Assessment of energy expenditure for physical activity using a triaxial accelerometer. Med Sci Sports Exerc 1994, 26:1516-1523.

97. Levine JA, Baukol PA, Westerterp KR: Validation of the Tracmor triaxial accelerometer system for walking. Med Sci Sports Exerc 2001, 33:1593-1597.

98. Bonomi AG, Plasqui G, Goris AH, Westerterp KR: Estimation of free-living energy expenditure using a novel activity monitor designed to minimize obtrusiveness. Obesity (Silver Spring) 2010, 18:1845-1851.

99. Brandes M, Rosenbaum D: Correlations between the step activity monitor and the DynaPort ADL-monitor. Clin Biomech (Bristol, Avon) 2004, 19:91-94.

100. Langer D, Gosselink R, Sena R, Burtin C, Decramer M, Troosters T: Validation of two activity monitors in patients with COPD. Thorax 2009, 64:641-642.

101. van Hees VT, van Lummel RC, Westerterp KR: Estimating activity-related energy expenditure under sedentary conditions using a tri-axial seismic accelerometer. Obesity (Silver Spring) 2009, 17:1287-1292.

102. Carter J, Wilkinson D, Blacker S, Rayson M, Bilzon J, Izard R, Coward A, Wright A, Nevill A, Rennie K, et al: An investigation of a novel threedimensional activity monitor to predict free-living energy expenditure. J Sports Sci 2008, 26:553-561.

103. Horner FE, Rayson MP, Bilzon JL: Reliability and validity of the 3DNX accelerometer during mechanical and human treadmill exercise testing. Int J Obes (Lond) 2011, 35(Suppl 1):S88-S97.

104. Hikihara Y, Tanaka S, Ohkawara K, Ishikawa-Takata K, Tabata I: Validation and Comparison of Three Accelerometers for Measuring Physical Activity Intensity During Nonlocomotive Activities and Locomotive Movements. J Phys Act Health 2011

105. Dugas LR, Carstens MA, Ebersole K, Schoeller DA, Durazo-Arvizu RA, Lambert $E V$, Luke $A$ : Energy expenditure in young adult urban informal settlement dwellers in South Africa. Eur J Clin Nutr 2009, 63:805-807.

106. Heil DP: Predicting activity energy expenditure using the Actical activity monitor. Res Q Exerc Sport 2006, 77:64-80.

107. Crouter SE, Schneider PL, Karabulut M, Bassett DR Jr: Validity of 10 electronic pedometers for measuring steps, distance, and energy cost. Med Sci Sports Exerc 2003, 35:1455-1460 
108. Spierer DK, Hagins M, Rundle A, Pappas E: A comparison of energy expenditure estimates from the Actiheart and Actical physical activity monitors during low intensity activities, walking, and jogging. Eur J App/ Physiol 2011, 111:659-667.

109. Crouter SE, Dellavalle DM, Horton M, Haas JD, Frongillo EA, Bassett DR Jr: Validity of the Actical for estimating free-living physical activity. Eur $J$ Appl Physiol 2011, 111:1381-1389.

110. Heiermann S, Khalaj Hedayati K, Muller MJ, Dittmar M: Accuracy of a portable multisensor body monitor for predicting resting energy expenditure in older people: a comparison with indirect calorimetry. Gerontology 2010, 57:473-479.

111. Duncan GE, Lester J, Migotsky S, Goh J, Higgins L, Borriello G: Accuracy of a novel multi-sensor board for measuring physical activity and energy expenditure. Eur J App/ Physiol 2011, 111:2025-2032.

112. Hooker SP, Feeney A, Hutto B, Pfeiffer KA, Mclver K, Heil DP, Vena JE, Lamonte MJ, Blair SN: Validation of the actical activity monitor in middleaged and older adults. J Phys Act Health 2011, 8:372-381.

113. Atallah L, Leong JJ, Lo B, Yang GZ: Energy expenditure prediction using a miniaturized ear-worn sensor. Med Sci Sports Exerc 2011, 43:1369-1377.

114. Manohar C, McCrady S, Pavlidis IT, Levine JA: An accelerometer-based earpiece to monitor and quantify physical activity. J Phys Act Health 2009, 6:781-789.

115. van Hees VT, Renstrom F, Wright A, Gradmark A, Catt M, Chen KY, Lof M, Bluck L, Pomeroy J, Wareham NJ, et al: Estimation of daily energy expenditure in pregnant and non-pregnant women using a wrist-worn tri-axial accelerometer. PLoS One 2011, 6:e22922

116. Ohkawara K, Oshima Y, Hikihara Y, Ishikawa-Takata K, Tabata I, Tanaka S: Real-time estimation of daily physical activity intensity by a triaxial accelerometer and a gravity-removal classification algorithm. Br J Nutr 2011, 105:1681-1691.

117. Annegarn J, Spruit MA, Uszko-Lencer NH, Vanbelle S, Savelberg HH, Schols AM, Wouters EF, Meijer K: Objective physical activity assessment in patients with chronic organ failure: a validation study of a new single-unit activity monitor. Arch Phys Med Rehabil 2011, 92:1852-1857. e1851.

118. Harris AM, McAlpine DE, Shirbhate R, Manohar CU, Levine JA: Measurement of daily activity in restrictive type anorexia nervosa. Int J Eat Disord 2008, 41:280-283.

119. Arvidsson D, Slinde F, Nordenson A, Larsson S, Hulthen L: Validity of the ActiReg system in assessing energy requirement in chronic obstructive pulmonary disease patients. Clin Nutr 2006, 25:68-74.

120. Hustvedt BE, Christophersen A, Johnsen LR, Tomten H, McNeill G, Haggarty $P$, Lovo A: Description and validation of the ActiReg: a novel instrument to measure physical activity and energy expenditure. Br J Nutr 2004, 92:1001-1008

121. Bussmann JB, Hartgerink I, van der Woude LH, Stam HJ: Measuring physical strain during ambulation with accelerometry. Med Sci Sports Exerc 2000, 32:1462-1471.

122. Mignault D, St-Onge M, Karelis AD, Allison DB, Rabasa-Lhoret R: Evaluation of the Portable HealthWear Armband: a device to measure total daily energy expenditure in free-living type 2 diabetic individuals. Diabetes Care 2005, 28:225-227.

123. St-Onge M, Mignault D, Allison DB, Rabasa-Lhoret R: Evaluation of a portable device to measure daily energy expenditure in free-living adults. Am J Clin Nutr 2007, 85:742-749.

124. Johannsen DL, Calabro MA, Stewart J, Franke W, Rood JC, Welk GJ: Accuracy of armband monitors for measuring daily energy expenditure in healthy adults. Med Sci Sports Exerc 2010, 42:2134-2140.

125. Koehler K, Braun H, de Marees M, Fusch G, Fusch C, Schaenzer W: Assessing energy expenditure in male endurance athletes: validity of the SenseWear Armband. Med Sci Sports Exerc 2011, 43:1328-1333.

126. Mackey DC, Manini TM, Schoeller DA, Koster A, Glynn NW, Goodpaster BH, Satterfield S, Newman AB, Harris TB, Cummings SR: Validation of an armband to measure daily energy expenditure in older adults. J Gerontol A Biol Sci Med Sci 2011, 66:1108-1113.

127. Cole PJ, LeMura LM, Klinger TA, Strohecker K, McConnell TR: Measuring energy expenditure in cardiac patients using the Body Media Armband versus indirect calorimetry. A validation study. J Sports Med Phys Fitness 2004, 44:262-271.
128. Fruin ML, Rankin JW: Validity of a multi-sensor armband in estimating rest and exercise energy expenditure. Med Sci Sports Exerc 2004, 36:1063-1069

129. Jakicic JM, Marcus M, Gallagher Kl, Randall C, Thomas E, Goss FL, Robertson RJ: Evaluation of the SenseWear Pro Armband to assess energy expenditure during exercise. Med Sci Sports Exerc 2004, 36:897-904.

130. Patel SA, Benzo RP, Slivka WA, Sciurba FC: Activity monitoring and energy expenditure in COPD patients: a validation study. COPD 2007 4:107-112.

131. Dwyer TJ, Alison JA, McKeough ZJ, Elkins MR, Bye PT: Evaluation of the SenseWear activity monitor during exercise in cystic fibrosis and in health. Respir Med 2009, 103:1511-1517.

132. Furlanetto KC, Bisca GW, Oldemberg N, Sant'anna TJ, Morakami FK, Camillo CA, Cavalheri V, Hernandes NA, Probst VS, Ramos EM, et al: Step counting and energy expenditure estimation in patients with chronic obstructive pulmonary disease and healthy elderly: accuracy of 2 motion sensors. Arch Phys Med Rehabil 2010, 91:261-267.

133. Hill K, Dolmage TE, Woon L, Goldstein R, Brooks D: Measurement properties of the SenseWear armband in adults with chronic obstructive pulmonary disease. Thorax 2010, 65:486-491.

134. Drenowatz C, Eisenmann JC: Validation of the SenseWear Armband at high intensity exercise. Eur J Appl Physiol 2011, 111:883-887.

135. Cavalheri V, Donaria L, Ferreira T, Finatti M, Camillo CA, Cipulo Ramos EM, Pitta F: Energy expenditure during daily activities as measured by two motion sensors in patients with COPD. Respir Med 2011, 105:922-929.

136. Berntsen S, Stafne SN, Morkved S: Physical activity monitor for recording energy expenditure in pregnancy. Acta Obstet Gynecol Scand 2010, 90:903-907.

137. Brazeau AS, Karelis AD, Mignault D, Lacroix MJ, Prud'homme D, RabasaLhoret R: Accuracy of the SenseWear Armband during ergocycling. Int J Sports Med 2011, 32:761-764.

138. Munguia-Izquierdo D, Santalla A, Legaz-Arrese A: Evaluation of a wearable body monitoring device during treadmill walking and jogging in patients with fibromyalgia syndrome. Arch Phys Med Rehabil 2012, 93:115-122.

139. Crouter SE, Churilla JR, Bassett DR Jr: Accuracy of the Actiheart for the assessment of energy expenditure in adults. Eur J Clin Nutr 2008, 62:704-711.

140. Lof M: Physical activity pattern and activity energy expenditure in healthy pregnant and non-pregnant Swedish women. Eur J Clin Nutr 2011, 65:1295-1301.

141. Kwon S, Jamal M, Zamba GK, Stumbo P, Samuel I: Validation of a novel physical activity assessment device in morbidly obese females. $J$ Obes 2010, 2010:1-8.

142. Borrell B: Epidemiology: every bite you take. Nature 2011, 470:320-322.

143. Schenk AK, Witbrodt BC, Hoarty CA, Carlson RH Jr, Goulding EH, Potter JF, Bonasera SJ: Cellular telephones measure activity and lifespace in community-dwelling adults: proof of principle. J Am Geriatr Soc 2011, 59:345-352.

144. Ades PA, Savage PD, Brochu M, Tischler MD, Lee NM, Poehlman ET: Resistance training increases total daily energy expenditure in disabled older women with coronary heart disease. J Appl Physiol 2005, 98:1280-1285.

145. Gosselink R, Troosters T, Decramer M: Peripheral muscle weakness contributes to exercise limitation in COPD. Am J Respir Crit Care Med 1996, 153:976-980.

146. Balashov K, Feldman DE, Savard S, Houde S, Frenette M, Ducharme A, Giannetti N, Michel C, Pilote L: Percent predicted value for the 6-minute walk test: using norm-referenced equations to characterize severity in persons with CHF. J Card Fail 2008, 14:75-81.

147. Pitta F, Troosters T, Probst VS, Spruit MA, Decramer M, Gosselink R Quantifying physical activity in daily life with questionnaires and motion sensors in COPD. Eur Respir J 2006, 27:1040-1055.

148. Tudor-Locke C, Williams JE, Reis JP, Pluto D: Utility of pedometers for assessing physical activity: convergent validity. Sports Med 2002, 32:795-808.

149. Baarends EM, Schols AM, Pannemans DL, Westerterp KR, Wouters EF: Total free living energy expenditure in patients with severe chronic 
obstructive pulmonary disease. Am J Respir Crit Care Med 1997, 155:549-554.

150. Vorrink SN, Kort HS, Troosters T, Lammers JW: Level of daily physical activity in individuals with COPD compared with healthy controls. Respir Res 2011, 12:33.

151. Watz H, Waschki B, Meyer T, Magnussen H: Physical activity in patients with COPD. Eur Respir J 2009, 33:262-272.

152. Murphy SL: Review of physical activity measurement using accelerometers in older adults: considerations for research design and conduct. Prev Med 2009, 48:108-114.

153. Schmidt ME, Steindorf K: Statistical methods for the validation of questionnaires-discrepancy between theory and practice. Methods Inf Med 2006, 45:409-413.

154. Bland JM, Altman DG: Applying the right statistics: analyses of measurement studies. Ultrasound Obstet Gynecol 2003, 22:85-93.

doi:10.1186/1479-5868-9-84

Cite this article as: Van Remoortel et al: Validity of activity monitors in health and chronic disease: a systematic review. International Journal of Behavioral Nutrition and Physical Activity 2012 9:84.

\section{Submit your next manuscript to BioMed Central and take full advantage of:}

- Convenient online submission

- Thorough peer review

- No space constraints or color figure charges

- Immediate publication on acceptance

- Inclusion in PubMed, CAS, Scopus and Google Scholar

- Research which is freely available for redistribution 